RPP-RPT-48340, Rev. 0

\title{
Evaluation of Alternative Strontium and Transuranic Separation Processes
}

\author{
C. S. Smalley \\ Washington River Protection Solutions, LLC \\ Richland, WA 99352 \\ U.S. Department of Energy Contract DE-AC27-08RV14800 \\ $\begin{array}{ll}\text { EDT/ECN: } & \text { DRF } \\ \text { Cost Center: } & \text { 2GB00 } \\ \text { B\&R Code: } & \text { N/A }\end{array}$ \\ UC: N/A \\ Charge Code: \\ B\&R Code: N/A Total Pages: 52
}

Key Words: Strontium, Transuranics, Strontium nitrate, Sodium permanganate, Complexants, AN-102, AN-107

Abstract: In order to meet contract requirements on the concentrations of strontium- 90 and transuranic isotopes in the immobilized low-activity waste, strontium- 90 and and transuranics must be removed from the supernate of tanks $241-\mathrm{AN}-102$ and $241-\mathrm{AN}-107$. The process currently proposed for this application is an in-tank precipitation process using strontium nitrate and sodium permanganate. Development work on the process has not proceeded since 2005 . The purpose of this evaluation is to identify whether any promising alternative processes have been developed since this issue was last examined, evaluate the alternatives and the baseline process, and recommend which process should be carried forward.

TRADEMARK DISCLAIMER. Reference herein to any specific commercial product, process, or service by trade name, trademark, manufacturer, or otherwise, does not necessarily constitute or imply its endorsement, recommendation, or favoring by the United States Government or any agency thereof or its contractors or subcontractors.
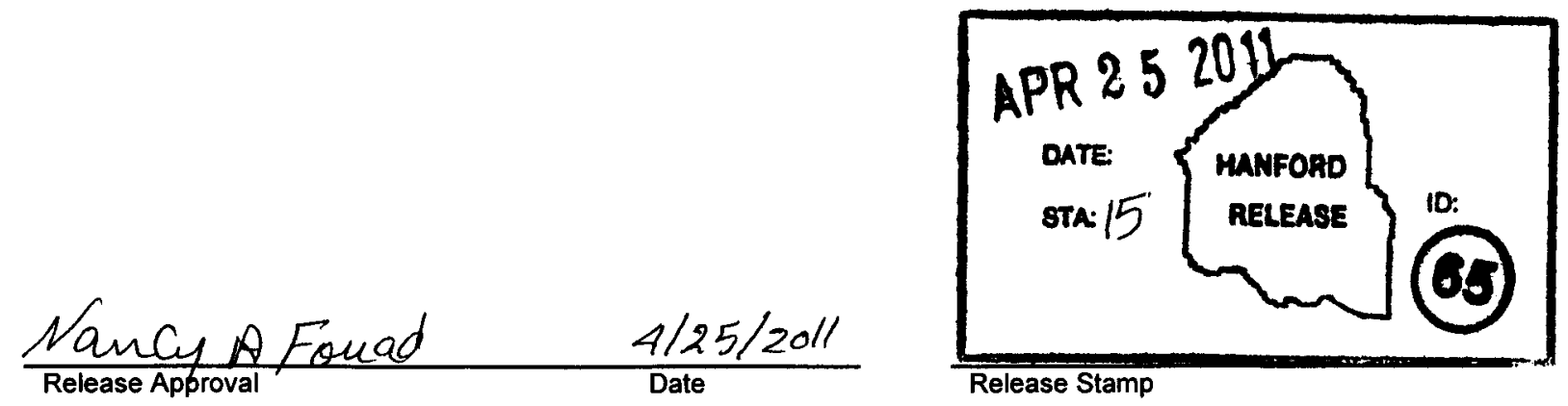

Approved For Public Release 


\section{Evaluation of Alternative Strontium and Transuranic Separation Processes}

C. S. Smalley

Washington River Protection Solutions, LLC

R. C. P. Hill

ELR Consulting, Inc.

Date Published

April 2011

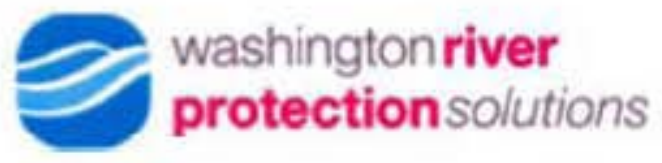

Post Office Box 850

Richland, Washington

Prepared for the U. S. Department of Energy

Office of River Protection 
RPP-RPT-48340, Rev. 0

\section{EXECUTIVE SUMMARY}

The Hanford Site tank farms consist of 177 underground tanks storing 56 million gallons of hazardous chemical and radioactive waste. The Waste Treatment and Immobilization Plant (WTP) is being built to process this waste by treating it and separating it into a low-activity waste (LAW) fraction that will contain most of the liquid waste, and a high-level waste (HLW) fraction that will contain the solids and most of the radioactivity.

Most of the radioactive strontium $\left({ }^{90} \mathrm{Sr}\right)$ and transuranic (TRU) isotopes in the tank waste are present in the sludge (solid) fraction, with low concentrations in the supernate (liquid) fraction. However, in double-shell tanks (DSTs) 241-AN-102 and 241-AN-107, the concentrations of these isotopes in the supernates are higher than in the supernates of other Hanford tanks due to the presence of higher concentrations of organic complexants. The complexants act as chelates and form highly soluble complexes with ${ }^{90} \mathrm{Sr}$ and TRU. The ${ }^{90} \mathrm{Sr}$ and TRU need to be removed from the supernate of these two tanks so that it can be processed into immobilized LAW (ILAW). The concentration limitations for ILAW state that ${ }^{90} \mathrm{Sr}$ cannot exceed 20 curies per cubic meter $\left(\mathrm{Ci} / \mathrm{m}^{3}\right)$ and TRU cannot exceed 100 nanocuries per gram $(\eta \mathrm{Ci} / \mathrm{g}){ }^{1}$

Based on the assumed sodium oxide loading of 20 weight percent (wt \%) and assumed glass density of 2.6 metric tons (MT) $/ \mathrm{m}^{3}$, for the target decontamination of $50 \%$ below the ILAW limits, $91.7 \%$ removal of ${ }^{90} \mathrm{Sr}$ and $54.0 \%$ removal of TRU is required for the AN-102 supernate, while $92.4 \%$ removal of ${ }^{90} \mathrm{Sr}$ and $92.8 \%$ removal of TRU is required for the AN-107 supernate.

A precipitation process using strontium nitrate and sodium permanganate was developed to perform this removal in the ultrafiltration feed vessels at the WTP. Due to the delay in processing HLW sludge that was projected to occur when the ultrafiltration feed vessels were occupied by the precipitation process, the possibility of performing the precipitation process in the tank farms was evaluated, as detailed in a 2005 report, RPP-24809, Strontium and TRU Separation Process in the DST System.

RPP-24809 concluded that a substantial cost savings could be achieved by performing the precipitation process in the tank farms, and recommended technology development activities that should be pursed before implementation. Based on this report, in-tank precipitation has been used as the baseline technology for ${ }^{90} \mathrm{Sr} / \mathrm{TRU}$ removal in the Hanford Tank Waste Operations Simulator (HTWOS) modeling and in system planning documents. However, technology development on the in-tank precipitation process has not proceeded since 2005.

The purpose of this evaluation is to identify whether any promising alternative processes have been developed since this issue was last examined, evaluate the alternatives and the baseline process, and recommend which process should be carried forward.

The alternative processes identified included filtration, sorption, advanced oxidation, thermal destruction, electrochemical destruction, and solvent extraction. Each process was evaluated based on its removal efficiency, processing conditions, additional waste generation, and schedule impact. The processes were then ranked.

\footnotetext{
${ }^{1}$ A nanocurie is one-billionth of a curie.
} 
In-tank precipitation with strontium nitrate and sodium permanganate was determined to be the preferred option for removing ${ }^{90} \mathrm{Sr}$ and TRU from $\mathrm{AN}-102$ and $\mathrm{AN}-107$ supernate. A path forward for developing this technology was identified, including testing to better quantify the impact of mixing on precipitate formation, and testing on undiluted waste. 


\section{TABLE OF CONTENTS}

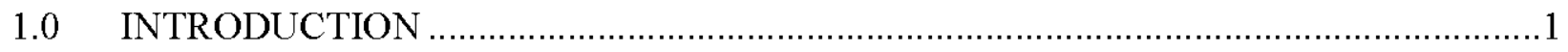

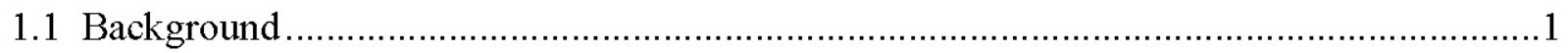

1.2 Purpose

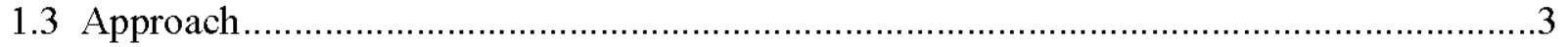

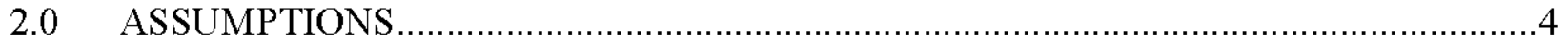

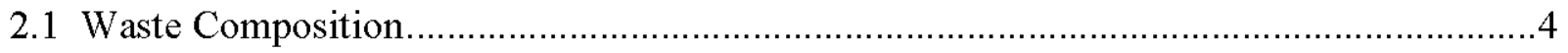

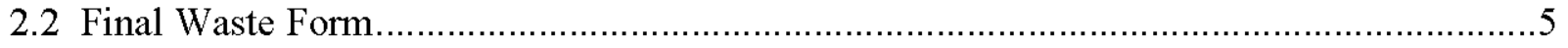

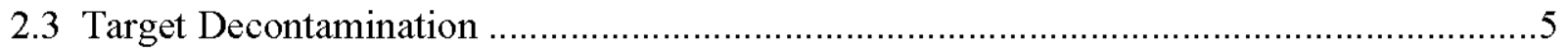

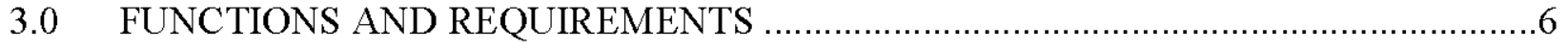

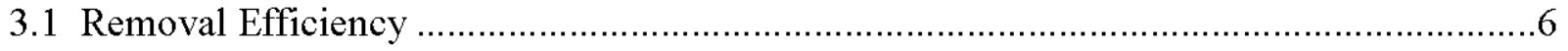

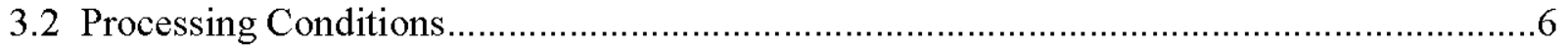

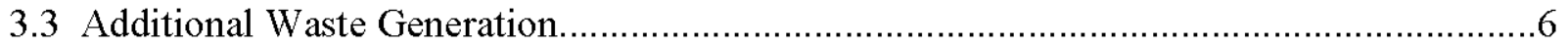

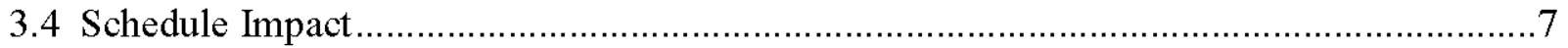

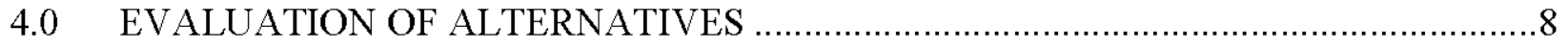

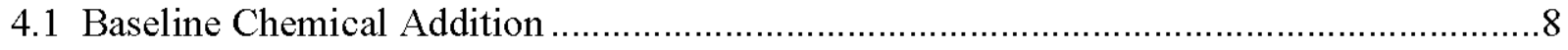

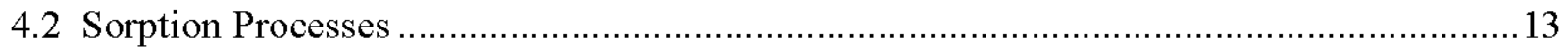

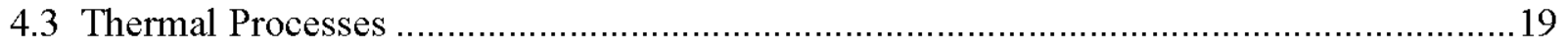

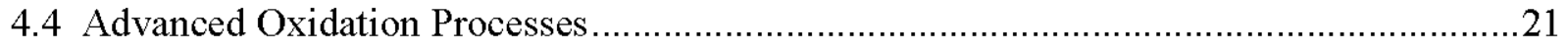

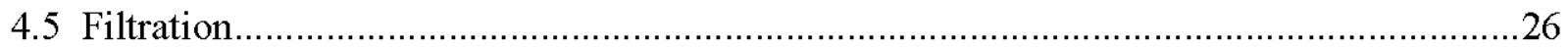

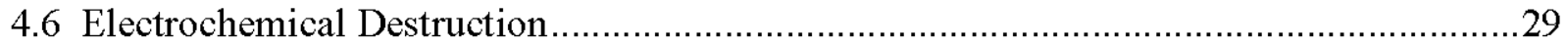

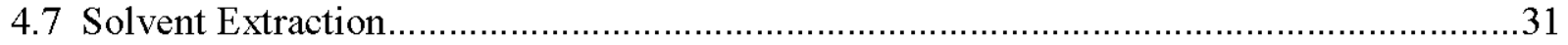

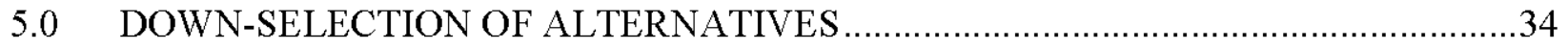

6.0 CONCLUSIONS AND RECOMMENDATIONS FOR FUTURE WORK …....................36

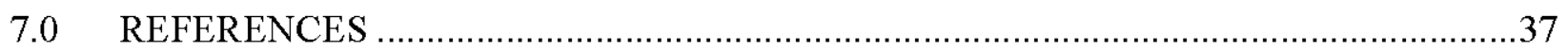

\section{APPENDICES}

Appendix A: Calculation of Removal Efficiency ................................................................. 42

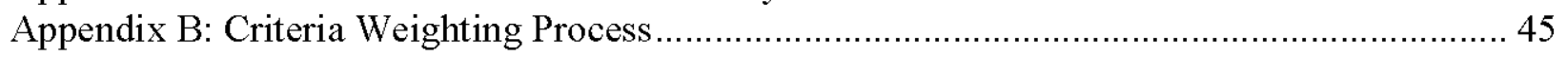

\section{TABLES}

Table 1: Organic Species in AN-102 Supernate …………............................................. 4

Table 2: Organic Species in AN-107 Supernate ………................................................... 5

Table 3: Concentrations of Concern for UV Oxidation Processes ………………………......... 25

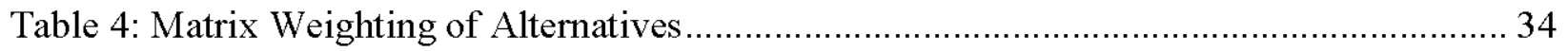


RPP-RPT-48340, Rev. 0

Abbreviations and Acronyms

AOP

BBI

Advanced Oxidation Process

DOE

Best Basis Inventory

DST

Department Of Energy

ED3A

Double-Shell Tank

EDDA

Ethylenediaminetriacetate

EDTA

Ethylenediaminediacetate

HEDTA

Ethylenediaminetetraacetate

HTWOS

Hydroxyethylethylenediaminetriacetate

HLW

Hanford Tank Waste Operations Simulator

IAEA

High-Level Waste

IDA

International Atomic Energy Agency

Iminodiacetate

ILAW

Immobilized Low-Activity Waste

$\mathrm{Kd}$

Distribution Coefficient

LANL

Los Alamos National Laboratory

LAW

Low-Activity Waste

NTA

Nitrilotriacetic Acid

NRC

Nuclear Regulatory Commission

SRS

Savannah River Site

SREX Strontium Extraction

TRL Technology Readiness Level

TRU Transuranic

TRUEX Transuranium Extraction

UV

Ultraviolet

WTP Waste Treatment and Immobilization Plant 
RPP-RPT-48340, Rev. 0

\subsection{INTRODUCTION}

The Hanford Site tank farms consist of 177 underground tanks storing 56 million gallons of hazardous chemical and radioactive waste. The WTP is being built to process this waste, treating it and separating it into a LAW fraction that will contain most of the liquid waste, and an HLW fraction that will contain the solids and most of the radioactivity. Both the HLW and LAW will then be vitrified.

Most of the radioactive ${ }^{90} \mathrm{Sr}$ and TRU isotopes in the tank waste are present in the sludge (solids) fraction, with low concentrations in the supernate (liquid) fraction. However, in DSTs 241-AN102 and 241-AN-107, the concentrations of these isotopes in the supernates are higher than in the supernates of other Hanford tanks due to the presence of higher concentrations of organic complexants. They act as chelates and form highly soluble complexes with the ${ }^{90} \mathrm{Sr}$ and TRU. The ${ }^{90} \mathrm{Sr}$ and TRU need to be removed from the supernate of these two tanks, so that it can be processed into ILAW.

\subsection{Background}

The requirement for TRU removal stems from a 1993 agreement ${ }^{2}$ between the Department of Energy (DOE) and the Nuclear Regulatory Commission (NRC) on waste incidental to reprocessing, which stated that radionuclides must be removed to the maximum extent technically and economically practical, for the waste to be classified as incidental. This agreement formed the basis for DOE M 435.1, Radioactive Waste Management Manual.

In 1997 the NRC provisionally agreed ${ }^{3}$ that for the Hanford tank waste, removal of radionuclides to the maximum extent technically and economically practical would include removing TRU from the supernate of three tanks containing "complexant concentrate" waste (AN-102, AN-107, and AY-101 ${ }^{4}$ ). Further, the agreement called for the incidental waste to be immobilized in a form that met Class $\mathrm{C}$ guidelines, as defined in Title 10, Code of Federal Regulations, Part 61, "Licensing Requirements for Land Disposal of Radioactive Waste," (10

\footnotetext{
${ }^{2}$ Letter, R. M. Bernero, Office of Nuclear Material Safety and Safeguards, U.S. NRC to J. Lytle, U.S. DOE, Office of Waste Management, Washington D.C., dated March 2, 1993.

${ }^{3}$ Letter, NRC to DOE, Richland Operations Office, "Classification of Hanford Low-Activity Tank Waste Fraction"; June 9, 1997, C. J. Paperiello, Director of Nuclear Material Safety and Safeguards, to J. Kinzer, Assistant Manager, Office of Tank Waste Remediation System, U. S. DOE, Richland Operations Office.

${ }^{4}$ The Best Basis Inventory data and the TRU removal efficiencies needed for these three tanks were reevaluated in 2004, when it was concluded that TRU removal was not required for AY-101, in Internal Letter 7G330 -MEJ-04003, "Re-assessment of Need to Remove Transuranic Elements from Tanks 241-AY-101, 241-AN-102, And 241AN-107 Low Activity Waste Fraction" (7G330 -MEJ-04-003 Letter).
} 
CFR 61). This regulation sets a $100 \mathrm{\eta Ci} / \mathrm{g}$ limit on TRU, and this limit has also been incorporated in the U.S. DOE, Office of River Protection Contract No. DE-AC27-01RV 14136, Specification 2.2.2.8, Radionuclide Concentration Limitations.

The Class $\mathrm{C}$ limit for ${ }^{90} \mathrm{Sr}$ is $7,000 \mathrm{Ci} / \mathrm{m}^{3}$, but here Specification 2.2 .2 .8 is more stringent, requiring the average ${ }^{90} \mathrm{Sr}$ concentration in the ILAW to be less than $20 \mathrm{Ci} / \mathrm{m}^{3}$.

Thus, ${ }^{90} \mathrm{Sr}$ and TRU need to be removed from the supernate of AN-102 and AN-107 so that the concentrations of these compounds in the final waste form comply with the contract specification: ${ }^{90} \mathrm{Sr}$ cannot exceed $20 \mathrm{Ci} / \mathrm{m}^{3}$ and TRU cannot exceed $100 \mathrm{\eta Ci} / \mathrm{g}$.

Removal of ${ }^{90} \mathrm{Sr}$ and TRU and destruction of organic complexants were areas of interest at Hanford for several years prior to the provisional 1997 NRC agreement, and many removal processes were evaluated including filtration, ion exchange, and thermal destruction of organic complexants. By 1997, precipitation had emerged as the preferred alternative, and was the proposed process for TRU removal, as documented in WHC-SD-WM-TI-699, Technical Basis for Classification of Low-Activity Waste Fraction from Hanford Site Tanks.

Development work continued on a precipitation process, which was planned to be implemented in the ultrafiltration feed vessels in the WTP pretreatment facility. Originally it was planned to use a ferric hydroxide precipitation process, but due to difficulties with filtering the precipitate, a process using strontium nitrate and sodium permanganate was developed (BNF-003-98-0171, Investigation of Varied Strontium-Transuranic Precipitation Chemistries for Crossflow).

However, implementing this process in the ultrafiltration feed vessels was estimated to cause a delay of six to 24 months in HLW processing, as those vessels are used for sludge processing as well. This processing delay generated interest in performing the precipitation process in the tank farms.

The in-tank precipitation concept was explored in a 2005 report, RPP-24809, that includes a mass balance and flowsheet for the in-tank precipitation process, as well as cost and schedule estimates. It was estimated that the in-tank precipitation would cost $\$ 2.6$ million to implement, and would "save six months of Waste Treatment and Immobilization Plant operating costs, currently estimated at approximately $\$ 1.2 \mathrm{M}$ per day” (RPP-24809).

\subsection{Purpose}

The in-tank precipitation process is used as the baseline technology for ${ }^{90} \mathrm{Sr}$ and TRU removal in the HTWOS modeling and in ORP-11242, Rev. 5, River Protection Project System Plan. Development work on this process has not proceeded since 2005, although RPP-24809 provided a list of items that would need to be resolved before full-scale implementation.

At this point in the mission, it is appropriate to identify whether any promising alternative processes have been developed since the issue was last examined, evaluate the alternatives against the baseline process of in-tank precipitation, and recommend which alternative should be carried forward. 


\section{RPP-RPT-48340, Rev. 0}

The purpose of this study is to:

- Identify new developments in processes for ${ }^{90} \mathrm{Sr}$ and TRU removal;

- Evaluate the alternative processes against the baseline process;

- Recommend which process should be used;

- Identify the future development work needed for the selected alternative.

\subsection{Approach}

The approach used for performing this evaluation was to:

- Identify the functions and requirements of the ${ }^{90} \mathrm{Sr} / \mathrm{TRU}$ removal process (Section 3.0);

- Perform a literature search to gather data on the baseline processes and the alternative technologies (Section 4.0);

- Evaluate the technologies against the functions and requirements, identifying a path forward for each technology (Section 4.0);

- Perform a downselect, using the information gathered in the evaluation process (Section 5.0);

- Recommend which removal process to pursue (Section 6.0). 
RPP-RPT-48340, Rev. 0

\subsection{ASSUMPTIONS}

The assumptions used in this evaluation are primarily related to waste composition and the calculation of the necessary removal efficiency.

\subsection{Waste Composition}

The composition of the waste in AN-102 and 107 was taken from the current Best Basis Inventory (BBI) data that has a decay date of January $12008,12: 00 \mathrm{AM}$. This data is documented in RPP-RPT-45764, Derivation of Best-Basis Inventory for Tank 241-AN-102, and RPP-RPT-46772, Derivation of Best-Basis Inventory for Tank 241-AN-107. The waste composition was used in the calculation of the removal efficiency needed to comply with ILAW requirements.

For the evaluation of removal processes, it was useful to know which organic species constitute the organic complexants, as different removal processes may be effective for different complexants. The BBI gives values for "Total Organic Carbon," but does not provide individual listings for the organic species that comprise this category (with the exception of oxalate). Based on a 1997 report, PNNL-11480, Speciation of Organic Carbon in Hanford Waste Storage Tanks: Part 1, the organic complexants may include, but not be limited to, hydroxyethylethylenediaminetriacetate (HEDTA), ethylenediaminetetraacetate (EDTA), ethylenediaminetriacetate (ED3A), ethylenediaminediacetate (EDDA), iminodiacetate (IDA), glycolate, oxalate and citrate.

More recent sample data is also available. Appendix B of RPP-RPT-45764 provides the analysis results for liquid grab samples taken from AN-102 in October 2009. A portion of the data is reproduced in Table 1. Concentrations for some individual organic species are provided, although the total organic carbon concentration indicates that other organic species are present.

Table 1: Organic Species in AN-102 Supernate

\begin{tabular}{|l|r|c|r|c|}
\hline \multicolumn{1}{|c|}{ Analyte } & Lower Limit & Mean & Upper Limit & Units \\
\hline Acetate & $1.25 \mathrm{E}+03$ & $1.30 \mathrm{E}+03$ & $1.34 \mathrm{E}+03$ & $\mu \mathrm{g} / \mathrm{mL}$ \\
\hline Formate & $1.05 \mathrm{E}+04$ & $1.08 \mathrm{E}+04$ & $1.12 \mathrm{E}+04$ & $\mu \mathrm{g} / \mathrm{mL}$ \\
\hline Glycolate & $1.27 \mathrm{E}+04$ & $1.30 \mathrm{E}+04$ & $1.34 \mathrm{E}+04$ & $\mu \mathrm{g} / \mathrm{mL}$ \\
\hline Oxalate & $4.39 \mathrm{E}+02$ & $4.54 \mathrm{E}+02$ & $4.69 \mathrm{E}+02$ & $\mu \mathrm{g} / \mathrm{mL}$ \\
\hline Total Organic Carbon & $2.70 \mathrm{E}+04$ & $2.81 \mathrm{E}+04$ & $2.92 \mathrm{E}+04$ & $\mu \mathrm{g} / \mathrm{mL}$ \\
\hline
\end{tabular}

RPP-RPT-45764, Derivation of Best-Basis Inventory for Tank 241-AN-102, Rev. 0

The most recent data on individual organic species in the AN-107 supernate is from WSRC-TR2003-00210, Compositing, Homogenization and Characterization of Samples from Hanford Tank 241-AN-107, which presents the results of a 2003 analysis of a composite of samples from 1998 and 2001. Data from this report is shown in Table 2. Concentrations of several organic 
species are listed individually, but the concentration of total organic carbon indicates that other organic species are present but were not accounted for individually.

Table 2: Organic Species in AN-107 Supernate

\begin{tabular}{|c|c|c|c|c|c|c|c|c|c|}
\hline Analyte & $\begin{array}{c}1 \mathrm{st} \\
\text { replicate } \\
(\mathrm{mg} / \mathrm{L})\end{array}$ & $\begin{array}{c}2 \text { nd } \\
\text { replicate } \\
(\mathrm{mg} / \mathrm{L})\end{array}$ & $\begin{array}{c}\text { 3rd } \\
\text { replicate } \\
(\mathrm{mg} / \mathrm{L})\end{array}$ & $\begin{array}{c}\text { Average } \\
(\mathrm{mg} / \mathrm{L})\end{array}$ & $\begin{array}{c}\% \\
\text { Relative } \\
\text { Standard } \\
\text { Deviation } \\
\end{array}$ & Blank (mg/L) & \begin{tabular}{|c|} 
Laboratory \\
Control \\
Standard \\
\% Recovery \\
\end{tabular} & $\begin{array}{c}\text { Matrix } \\
\text { Spike \% } \\
\text { Recovery }\end{array}$ & $\begin{array}{c}\text { Quality } \\
\text { Control } \\
\text { Flag }\end{array}$ \\
\hline HEDTA & 1111 & 935 & 1321 & 1123 & 17 & $<10$ & 95 & 92 & - \\
\hline EDTA & 3607 & 3403 & 3870 & 3627 & 6 & $<10$ & 105 & 93 & - \\
\hline DA & 3783 & 4344 & 4034 & 4054 & 7 & $<25$ & 109 & 107 & - \\
\hline Formate & 11503 & 10332 & 11503 & 11112 & 6 & $<100$ & 102 & 113 & - \\
\hline Oxalate & 694 & 591 & 705 & 663 & 10 & $<100$ & 100 & 105 & - \\
\hline Citrate & 12124 & 12435 & 12021 & 12193 & 2 & $<10$ & 94 & 95 & - \\
\hline Gy colate & 24767 & 24870 & 24767 & 24801 & 0.2 & $<10$ & 86 & 125 & - \\
\hline Acetate & 1534 & 1420 & 1368 & 1440 & 6 & $<10$ & 87 & 67 & US \\
\hline Total Organic Carbon & 27200 & 34500 & 38200 & 33300 & 17 & 9.44 & 101 & 99 & |UR \\
\hline
\end{tabular}

Quality Control Flags: None - meets all quality control UR - fails \% relative standard deviation criteria US - fails \% recovery of matrix sp ike W SRC-TR-2003-00210, Compositing, Homogenization and Characterization of Samples from Hanford Tank 241-AN-107, Rev. 0

\subsection{Final Waste Form}

The final waste form for the LAW fraction of the AN-102 and AN-107 waste was assumed to be glass with a density of $2.6 \mathrm{MT} / \mathrm{m}^{3}$ and a sodium oxide loading of $20 \mathrm{wt} \%$, based on the assumptions used in ORP-11242, Rev. 5 (B3.3.4.5 and B3.3.4.7). Twenty weight percent is the maximum sodium oxide loading for the LAW glass, and was used for conservatism.

If a different waste form were used, such as the immobilized product from fluidized bed steam reforming, it would be necessary to recalculate the removal efficiency (Section 3.1).

\subsection{Target Decontamination}

The target decontamination for the removal process was assumed to be $50 \%$ below the ILAW limits, based on RPP-24809, which stated that "the $50 \%$ values were conservatively selected as preliminary process limits to avoid exceeding the contractual WTP ILAW glass limits due to data uncertainties (e.g. $\mathrm{Na}_{2} \mathrm{O}$ loading, $\mathrm{Sr}$ /TRU concentrations, etc.)." 


\subsection{FUNCTIONS AND REQUIREMENTS}

To provide a basis for comparison of the alternatives, the functions and requirements of the

${ }^{90} \mathrm{Sr}$ /TRU removal process were identified. This listing of functions and requirements is not comprehensive, but highlights the major requirements.

\subsection{Removal Efficiency}

The selected process must remove an amount of ${ }^{90} \mathrm{Sr}$ and TRU from the supernate such that the concentrations of ${ }^{90} \mathrm{Sr}$ and TRU in the final waste form meet the ILAW concentration requirements $\left({ }^{90} \mathrm{Sr}\right.$ cannot exceed $20 \mathrm{Ci} / \mathrm{m}^{3}$ and TRU cannot exceed $\left.100 \mathrm{\eta Ci} / \mathrm{g}\right)$.

Based on the assumed sodium oxide loading of $20 \mathrm{wt} \%$ and assumed glass density of 2.6 $\mathrm{MT} / \mathrm{m}^{3}$, for the target decontamination of $50 \%$ below the ILAW limits, $91.7 \%$ removal of ${ }^{90} \mathrm{Sr}$ and $54.0 \%$ removal of TRU is required for the AN-102 supernate, while $92.4 \%$ removal of ${ }^{90} \mathrm{Sr}$ and $92.8 \%$ removal of TRU is required for the AN-107 supernate. The details of the removal efficiency calculations are shown in Appendix A.

\subsection{Processing Conditions}

If the selected removal process is to be performed in-tank, the processing conditions must comply with the DST requirements on waste temperature, waste chemistry, and other items.

OSD-T-151-00007, Operating Specifications for the Double-Shell Storage Tanks, sets the maximum waste temperature at $350^{\circ} \mathrm{F}$ for tanks in AN Tank Farm.

The chemistry limits in Table 1.5.1-1 of OSD-T-151-00007 govern the nitrate, nitrite, and hydroxide concentration of the DST waste.

In the course of evaluating the alternative technologies, some processes were found to require implementation ex-tank. While operating specifications for an ex-tank process would have to be developed based on the specific process, one general constraint is that the treated waste would need to be returned to a DST, and thus would need to comply with the DST operating specifications.

\subsection{Additional Waste Generation}

One goal of the process is to minimize the amount of HLW generated. Minimizing secondary waste generated by the process, such as off-gases, is also important. 
RPP-RPT-48340, Rev. 0

\subsection{Schedule Impact}

Another important criterion is the schedule impact of the process. In the HTWOS modeling for ORP-11242, Rev. 5, treatment of AN-102 and AN-107 waste takes place in the period from 2028 to 2031 (SVF-1922, Transfers_MMR-10-032-JHF-2-GKA-5.4-8.4r0-2010-07-14-at-23-55$05 . x(\mathrm{sm})$. The selected process should be able to meet this timeline. Whether a process can meet this timeline depends partly on its technology readiness level (TRL), and partly on the processing time required.

The TRLs of the alternative processes were evaluated using the criteria presented in Attachment D of Technology Readiness Assessment (TRA) / Technology Maturation Plan (TMP) Process Guide, a 2008 DOE report. 


\subsection{EVALUATION OF ALTERNATIVES}

The technologies evaluated fall into seven main categories: chemical addition, sorption processes, thermal destruction, advanced oxidation processes, filtration processes, electrochemical destruction, and solvent extraction.

- Chemical addition processes add chemicals to the supernate, in order to oxidize the complexants, substitute for ${ }^{90} \mathrm{Sr}$ and TRU in the complexes, or form a co-precipitant.

- Sorption processes use ion exchange resins or other absorbers to capture ${ }^{90} \mathrm{Sr}$ and TRU within their chemical structure.

- Thermal destruction processes heat the supernate to induce the nitrite and nitrate already present to oxidize the organic complexants.

- Advanced oxidation processes are ambient pressure and temperature processes that use the hydroxyl radical as an oxidizer.

- Filtration processes are physical separation processes that use porous mediums to separate ${ }^{90} \mathrm{Sr}$ and TRU from the supernate.

- Electrochemical destruction processes oxidize the organic complexants at the anode of an electrochemical cell.

- Solvent extraction processes partition the ${ }^{90} \mathrm{Sr}$ and TRU to a solvent that can be separated from the remainder of the supernate.

However, there is overlap between these categories. For example, many advanced oxidation processes involve chemical additions.

In the following subsections, the results of the literature search for each technology are summarized, and each technology is evaluated against the criteria identified in Section 3.0: removal efficiency, processing conditions, additional waste generation, and schedule impact. A path forward is identified for each technology, listing steps that could be taken to further develop it.

\subsection{Baseline Chemical Addition}

In nuclear waste treatment facilities, chemical addition is a standard method of partitioning waste constituents. At Hanford it is currently the baseline method for pretreatment of Tanks AN-102 and AN-107. The baseline process is to be performed by two chemical additions to the wastes. The first adds non-radioactive strontium ion to obtain an isotopic dilution of ${ }^{90} \mathrm{Sr}$ in the complexes. The second adds permanganate ion that oxidizes the chelates, solvating the TRU metal ions and facilitating precipitation of them with the reaction product and co-precipitant (manganese dioxide). 


\subsubsection{Introduction}

Initial studies evaluating chemical addition for removing ${ }^{90} \mathrm{Sr}$ and TRU metals from Tanks AN102 and $\mathrm{AN}-107$ were directed at displacing them from the chemical complexes in which they were solvated (Internal Memorandum 12110-PCL94-026, "Strontium Removal by Precipitation" (12110-PCL94-026 - Memorandum) and "The Displacement of Sr from Organic Chelates by Hydroxide, Carbonate, and Calcium in Concentrate Electrolytes [Felmy and Mason 1998]). The strategy was to break the metal ion to chelate bond with a chemical species that could form stronger bonds with either the metal ion or the chelate with which it was complexed. This reaction would be followed by the free metal ion precipitating from solution with one of the waste constituent anions. Manganese, calcium, nickel, sodium and non-radioactive strontium were among the ions tested (12110-PCL94-026 - Memorandum). Results from the studies supported displacement chemical addition as a pretreatment methodology and also led to future studies that targeted more detailed evaluations of "isotopic dilution" using non-radioactive strontium. The use of non-radioactive strontium was a result of these studies confirming that strontium will readily exchange locations between being in a complex and being solvated. Hence, additional non-radioactive, solvated strontium will be able to displace radioactive strontium from the complexes.

These early studies also evaluated co-precipitation to enhance precipitation of ${ }^{90} \mathrm{Sr}$ and TRU metals from the supernate wastes in which they have inherently low solubility. Ferric ion, which forms a ferric hydroxide precipitate, and permanganate, which forms a manganese dioxide precipitate, were tested for use in co-precipitation (BNF-003-98-0171).

Ultimately, a process using strontium nitrate and sodium permanganate was developed (PNWD3340, Assessment of Sr/TRU Removal Mechanisms Using AN-102 and AN-107 Tank Waste Samples). The studies on this process were targeted to the WTP operating conditions because the pretreatment process was to be performed in the WTP. Although the findings in these studies were most directly applicable to the WTP, they were used to support decision making for the current baseline method for the tank farms pretreatment application. Hence, the planned tank farms process is to add non-radioactive strontium ion as strontium nitrate to the supernate, followed by adding permanganate ion as sodium permanganate. The objective is to have both

${ }^{90} \mathrm{Sr}$ and the TRU metals partition and precipitate in-situ from the tank supernate into the tank sludge.

A brief description of the underlying chemistry for the baseline chemical addition process follows. Non-radioactive strontium is added to dilute the concentration of ${ }^{90} \mathrm{Sr}$ retained in the complexes and assure a supersaturated solution of strontium. Supersaturation ensures that the strontium will readily precipitate, most likely as strontium carbonate. Permanganate is added to oxidize the organic chelates, releasing the complexed metal ions into solution as free ions.

Manganese dioxide is a reaction product from the permanganate, which acts as a co-precipitating agent for the inherently dilute TRU metal ions.

Most of the development work on the strontium nitrate/sodium permanganate addition has been performed on a laboratory scale. Several factors associated with this work may prove to be significant for the future. One factor is that the testing was performed with simulants and wastes 
adjusted to a 5.5 sodium ion molarity, which corresponds to the sodium ion molarity required for the ultrafiltration process in the WTP. This requirement resulted in a dilution of about two for the waste simulants and actual waste samples used in the testing. Another significant factor was that magnetic stirring was usually performed, which imposes a relatively high shear on the reaction mixture. Finally, during the course of the testing it was discovered that the formation reactions of the precipitates were much slower than the displacement and oxidation reactions.

A search of some of the available literature did not identify current applications used in the nuclear industry with similar waste materials. This lack of other applications may be due to the unique combination of quantities, chemical and physical compositions and method of containment in the Hanford wastes in Tanks AN-102 and AN-107. It may also be that other entities have not divulged information about their management practices with similar nuclear fuel processing wastes.

\subsubsection{Evaluation}

In the course of the work for this technical review, no definitive reason for not pursuing the use of chemical addition technology was identified. Other factors such as laboratory and scale-up activities, engineering design considerations, operations constraints and requirements or programmatic issues may preclude implementing it. However, these factors are not within the scope of this study.

\subsubsection{Removal Efficiency}

As documented in PNWD-3340, percent removals of $\sim 94 \%$ for ${ }^{90} \mathrm{Sr}$ and $75-85 \%$ for ${ }^{241}$ Am were achieved using the optimized reagent additions and processing conditions. These removals would meet the ILAW specifications, although the TRU removal for AN-107 would not meet the target of $50 \%$ below the ILAW specification.

Removal efficiency does not have a significant sensitivity to small variations in the chemical reactions of the process. The addition of strontium nitrate followed by the addition of sodium permanganate is based on chemistry that has been well characterized over many years in the chemical literature (Advanced Inorganic Chemistry, A Comprehensive Text, Cotton and Wilkinson, 1980). In the testing it was discovered that strontium nitrate addition to simulants and actual wastes resulted in rapid exchange of the strontium in solution with the strontium held in the complexes. This result is as expected because strontium is known to readily exchange between being solvated and being in organic complexes such as the ones expected to be present in the AN-102 and AN-107 supernates. Also, it was discovered that at ambient temperatures permanganate readily oxidizes organic waste constituents. It was found that this oxidation, whether partial or complete, was enough to release most of the complexed metal ions into solution. This reaction was also expected because of the strong oxidative power of permanganate ion. Hence, the testing substantiated the robustness of this chemical addition methodology and demonstrated that it is based on "tried and true" chemical reactions. 
One of the factors that may significantly impact removal efficiency is the nature of the precipitate that is formed in the process. If the precipitate is not readily partitioned out of the supernate and into the sludge, the removal efficiency may be directly impacted.

Precipitate structure and rate of growth can be very dependent on the solvent matrix in which the precipitate is being formed. The temperatures, mixing rate and concentration of reagents and the solubility of the precipitate at the time of precipitation, are all variables factoring into the relative supersaturation of the system. For this reason, it may be significant that almost all of the testing to date has been done on diluted actual wastes and simulants that were generally subjected to high shear mixing conditions. The size of particles making up a precipitate affects the ease and completeness of the filtering operation. The physical properties of a solid-liquid mixture change continuously as the particle size of the solid phase increases. Thus, over time the precipitate may become a more crystalline solid and much more amenable to filtration.

\subsubsection{Processing Conditions}

As detailed in RPP-24809, this process is compatible with the DST operating specifications. The process is performed at ambient temperature, does not require $\mathrm{pH}$ adjustment, and does not disrupt the nitrite/nitrate ratio. The processing sequence assumed by HTWOS is described in Section 12.0 of RPP-17152, Hanford Tank Waste Operations Simulator (HTWOS) Version 6.0 Model Design Document. The currently planned precipitation process is performed in a strike tank that is required to have available space, two mixer pumps, and a transfer pump. First a 50,000 gallon batch is transferred from $\mathrm{AN}-102$ to the strike tank, and the precipitation process is performed as a demonstration of its effectiveness. The remaining supernate from AN-102 and AN-107 is treated in $\sim 400,000$ gallon batches. Future testing and tank farms operations conditions may lead to a revision of these currently planned process conditions.

\subsubsection{Additional Waste Generation}

The strontium nitrate and sodium permanganate additions would increase the volume of HLW.

\subsubsection{Schedule Impact}

The work completed on the in-tank precipitation process satisfies some of the criteria needed to reach TRLs from 1 to 4 , but none of the levels have been fully completed. The process has been tested several times on both simulants and samples of actual AN-102 and AN-107 waste. The largest scale experiments performed to this point used 920 liters of simulant in cross-flow filtration testing, as described in WSRC-TR-2003-00204, Final Report: Pilot-Scale Cross-Flow Ultrafiltration Test Using a Hanford Site Tank 241-AN-102 Waste Simulant (U).

\subsubsection{Path Forward}

The path forward is based on recognition that there are differences between performing chemical addition in the WTP and in tank farms. It may be that in applying this technology in the tank farms it is more feasible not to dilute the supernates to a sodium ion molarity of 5.5, but to add the chemicals directly to the supernates, where the current sodium molarities are 9.3 and 9.2 in 
AN-102 and AN-107, respectively. If the supernate is not diluted, extra tank space will not be needed and it may be possible to perform the chemical additions in Tanks AN-102 and AN-107 without performing a waste transfer. However, in order to perform the additions in-tank, some of the prior chemical testing will need to be repeated with undiluted simulants and actual wastes, in order to determine the optimal conditions for formation of precipitates and suspended solids. Most probably, because of the increased concentrations, the formation reactions will occur more readily. Thus far, one test on undiluted waste was performed in support of RPP-24809, as documented in Internal Memorandum 7S110-RWW-05-017, "Test Results for At-Tank Conditions for Strontium/Transuranic Removal from Tank 241-AN-107 Supernatant" (7S110RWW-05-017-Memorandum). Similar removal efficiencies were seen for diluted and undiluted waste, and further testing with undiluted waste was recommended in RPP-24809.

However, it remains necessary to partition the ${ }^{90} \mathrm{Sr}$ and the TRU metal ions in situ so that they remain with the solid waste and not in the supernate. This aspect of the in-tank process needs the most work in the path forward. The challenge associated with this partitioning stems from the low levels of concentration of strontium and the TRU metal ions in the supernates and the need to form precipitates that do not re-dissolve into the supernate or other carrier used to deliver the sludge to the WTP.

In the best case for partitioning, strontium and TRU metals would simply precipitate out of the supernate in sufficient quantities to bring the supernate within acceptance and compliance specifications and requirements. Achieving these quantities may prove to be possible. In prior testing, the supernates were diluted and mixed very rapidly and vigorously. These are conditions that may lead to formation of hydrated precipitates. Future testing would be performed at undiluted concentrations and with slow non-vigorous mixing rates.

The limiting cases involve reaction product solids forming as suspended solids and not precipitating into the sludge or tank bottoms. In these cases, they may form colloids, polymers or flocculants. If required, future testing would be directed at identifying the physical nature of the reaction product solids and the best physical or chemical method for removing them from the supernate and placing them in the solid waste.

Additionally, the long term stability of the precipitate has not been characterized. In previous testing, the precipitate was separated from the supernate within a matter of hours via filtration. This is a very short time when compared to performing a similar process in tank farms. In the tank farms, the minimum residence time of the precipitate in contact with the supernate will be six months due to sampling time requirements before transferring batches to the WTP. In all probability the residence times will prove to be longer than six months due to program and operations needs and requirements. Hence, future testing may be directed at measuring the long term stability of the precipitate in order to establish that during extended time periods the ${ }^{90} \mathrm{Sr}$ and TRU metals do not become significantly re-solvated.

The following is an outline of areas to test to identify treatment process parameters that may prove to be important. Testing would be performed with undiluted simulants and actual waste samples unless dilution proved to enhance the process. 


\subsubsection{Precipitate Stability Testing}

This testing is performed to evaluate the stability of the precipitate over longer periods of time, representative of the potential residence time in tank farms.

- Perform the precipitation process

- Measure the decontamination factors initially, and after various time intervals

\subsubsection{Chemical Addition}

This testing is performed to obtain information about the optimal chemical addition sequence, methods of addition, and, if required, the optimal method for partitioning strontium and TRU metal ions from the reaction mixture after chemical addition.

- Addition of permanganate ion to simulant/waste will:

O Observe addition rate;

- Observe mixing rate;

- Identify type of solid formed;

- Identify effective partition method (i.e. physical/chemical method versus time).

- Addition of strontium ion after the above permanganate addition will:

- Observe addition rate;

- Observe mixing rate;

- Identify type of solid formed;

- Identify effective partition method (i.e. physical/chemical method versus time).

\subsubsection{Process Optimization}

This testing is performed to evaluate whether the process can be further optimized. This testing will evaluate:

- Effects of temperature;

- Effects of dilution.

\subsection{Sorption Processes}

Sorption processes involve the use of ion exchange resins or other absorbers to capture ${ }^{90} \mathrm{Sr}$ and TRU within their chemical structure. Several types of absorbers have been investigated for this purpose, including organic, inorganic and chelating absorbers. 


\subsubsection{Introduction}

Absorption technology can be applied in waste pretreatment to remove ${ }^{90} \mathrm{Sr}$ and TRU metals from the AN-102 and AN-107 supernates. Studies were conducted to identify the best absorbers for this purpose, with most of the initial work being done at the Los Alamos National Laboratory (LANL), as documented in LA-12654, LA-12863, LA-12862, LA-12943, and LA-13000.

The early LANL work (LA-12654) targeted the chemistry of Tank SY-102. At the time of this study, the mission was to remediate the large quantities of hazardous waste stored in this tank. In these tests, the absorbers were placed in hypodermic syringes modified by the placement of a Kynar ${ }^{5}$ filter in the syringe tip. The simulant solution was drawn through the filter into the syringe. The syringes were placed on a tube rotator for the contact period. The absorption of 14 elements on 60 absorbers was studied. The elements included strontium and the TRU metals plutonium and americium $\left({ }^{241} \mathrm{Am}\right)$. The absorbers included a very wide range that included cation and anion exchange resins, inorganic exchangers, composite absorbers and a series of liquid extractors absorbed on porous support beads. Two simulants were used. One represented acid-dissolved sludge and the other an alkaline supernate, both formulated to represent the best known chemical constituency of waste in Tank SY-102. The reaction conditions were ambient temperature and up to six hours reaction time. None of the absorbers used in this work performed well enough to be used with the supernates of Tanks AN-102 and AN-107 to remove ${ }^{90} \mathrm{Sr}$ or TRU metals.

A follow up study (LA-12863) at LANL evaluated 15 elements on 58 absorbers with a simulant for DST Slurry Feed with similar reaction conditions. More than 20 absorbers were identified that absorbed strontium well. Five absorbers absorbed ${ }^{241} \mathrm{Am}$ marginally well (no other TRU metals were included in the study). Titanate absorbers performed well, and were included in the follow on work.

The next set of studies, described in a series of three papers, considered the difficulties of absorbing metal ions in solution as complexed chemical species (LA-12862, LA-12943, and LA13000). The first part of the series quantified the extent to which degraded organic compounds seriously interfere with the absorption of the metals (LA-12862). It was targeted to strontium absorption with an irradiated simulant representing Tank SY-101 supernate. The constituents of the simulant were EDTA and some of its possible radiolysis products. This study included 18 of the absorbers from the earlier work that had shown good results for strontium absorption. A wide variety of absorbers were used, including titanates such as monosodium titanate and crystalline silicotitanate. Procedure conditions were first a dilution of the simulant to $3: 1$ with reaction conditions of ambient temperature up to six hours.

The work in this second and third parts of the series was markedly different from the earlier work in that pretreatment steps were taken in which the simulant was heated, irradiated or both heated and irradiated prior to reaction with the absorbers. The objective of the pretreatment was to destroy the organic complexants so that the metals were no longer complexed, but solvated, making them much more amenable to being absorbed. In the second part of the series, 32

\footnotetext{
${ }^{5}$ Kynar ${ }^{\circledR}$ is a registered trademark of Arkema Incorporated, Philadelphia, PA
} 
absorbers with known high absorption for the metals when not in the presence of complexants were used (LA-12943). Four variations of SY-101 simulant were used. This testing identified four absorbers capable of absorbing strontium in the presence of complexants, and some absorbers that removed ${ }^{241} \mathrm{Am}$. One of these absorbers, for example, was monosodium titanate. Absorption of the metals was generally greatly enhanced with the pretreatment steps. The thermal pretreatment was at $450^{\circ} \mathrm{C}$ for 25 seconds at 15,000 pounds per square inch (psi) pressure. The irradiation pretreatment was performed with gamma irradiation at 1.35 millirads per hour (Mrads/hr) to a total of $34 \mathrm{Mrads}$ using cobalt $\left({ }^{60} \mathrm{Co}\right)$. In the final and third part of the series, the simulant was prepared with a wider array of complexants that included the three chelates EDTA, HEDTA and NTA, as well as three organic complexing ions -- citrate, gluconate and IDA (LA-13000). This simulant was subjected to various ratios of dilution from $0,0.5,2.0$ and 3.0, as well as to the pretreatment processes of heating and irradiation as described above. It was concluded that select absorbers are capable of removing strontium and some TRU metals without requiring first destruction or removal of the complexants, although not at the $\sim 93 \%$ removal efficiency required for application to the AN-102 and AN-107 supernate. It was also advised that further work would be required using actual tank waste supernate samples to verify these findings.

Research on adsorption processes was conducted at the University of Washington from 1996 to 1999, in a project for the DOE Environmental Management Science Program (DOE/ER/62313, Adsorption/Membrane Filtration as a Contaminant Concentration and Separation Process for Mixed Wastes and Tank Wastes). This research included the investigation of iron oxide coated sand in packed columns to adsorb strontium, but adsorption of TRU was not tested. The columns were regenerated with a dilute solution of nitric acid. The iron oxide coated sand was found to have good selectivity for strontium, and was tested with simulants of Hanford singleshell tank waste, both with and without EDTA. It was found that strontium retention was reduced by the presence of EDTA, in a manner dependent on the EDTA/Ca ratio, suggesting that calcium was competing with strontium for the EDTA. Some preliminary testing was performed using iron oxide coated sand at the Savannah River Site (SRS), but this technology does not appear to have been pursued further.

Research was also conducted on ion exchange materials for cesium and strontium removal at Texas A\&M University, in a project for the DOE Environmental Management Science Program (DOE/ER/14689, Cesium and Strontium Specific Exchangers for Nuclear Waste Effluent Remediation - Final Report). This work included sodium nonatitanate, clinoptolite, and other inorganic absorbers. Good removal efficiencies for strontium were found for several of the absorbers in the testing without complexants, but for testing with complexants metal substitution with calcium was used to make the strontium available to the absorbers. TRU absorption was not tested in this work.

A monosodium titanate process is being used to remove ${ }^{90} \mathrm{Sr}$ and TRU from salt waste streams at SRS. However, these wastes do not contain organic complexants. A 2008 paper provides a good overview of the differences between SRS and Hanford wastes, and the reasons for selection of different treatment technologies at each site (SRNL-STI-2008-00426, The Role of Liquid Waste Pretreatment Technologies in Solving the DOE Clean-Up Mission). 
Later work done on a worldwide basis has been reported in the literature from the International Atomic Energy Agency (IAEA). The IAEA conducted a Coordinated Research Project and issued a report in February 2003, IAEA-TECDOC-1336, Combined Methods for Liquid Radioactive Waste Treatment. The advances made were divided into three classes or types:

- Materials with Combined Properties;

- Combined Single Stage Processes;

- Combined Multi-Stage Processes.

Materials with Combined Properties have been shown to have high capacity and selectivity for radionuclides such as ${ }^{90} \mathrm{Sr}$ and the actinides. These materials may be chitin-based with a fiber structure, or titanium dioxide-based sorbents. Some of the work associated with these materials has been done in the Russian Federation and in Czechoslovakia. These materials can interact with the waste supernates and employ dual features such as co-precipitation and absorption. It has been suggested that these materials can perform much better than crystalline silicotitanate, ion exchange, zeolites, and others when the wastes contain complexing agents.

Combined Single Stage Processes are those in which two or more treatment techniques are combined. These techniques could include electrosorption, photo-catalytic oxidation combined in one stage with sorption or multi-layer sorption processes. In the three techniques listed, different components for waste treatment are combined in a single unit. This work has been developed in the Russian Federation, Hungary and the Czech Republic. Scale-up facilities for these processes have been built in the Russian Federation at the Bochvar Research Center, Moscow, but results from these scale-up facilities were not readily available.

Combined Multi-Stage Processes are suggested as applicable to liquid radioactive wastes with varied nature and composition -- that is, "problematic" radioactive wastes with complex compositions. Combinations can include such things as sorption with membrane filtration, centrifugation for colloid containing waste streams or precipitation for liquid radioactive wastes. This work has been developed in Belgium, China, Bulgaria, Belarus, India, Malaysia, Korea and the Czech Republic.

\subsubsection{Evaluation}

This review did not identify a definitive reason for not further pursuing the use of absorbers. However, constraints and requirements of this technology may preclude implementation in the Hanford tank farms.

\subsubsection{Removal Efficiency}

Removal efficiency of the absorbers was evaluated based on the distribution coefficient (Kd) values for ${ }^{90} \mathrm{Sr}$ and TRU metals absorption. The distribution coefficient is defined as follows:

$$
K d=\frac{(P r-P o) S}{P o A}
$$


where:

$$
\begin{aligned}
& \mathrm{Pr}=\text { measured pre-contact activity per milliliter } \\
& \mathrm{Po}=\text { measured post-contact activity per milliliter } \\
& \mathrm{S}=\text { milliliters of solution contacted } \\
& \mathrm{A}=\text { grams of dry absorber contacted }
\end{aligned}
$$

Early work performed primarily at LANL scanned a considerable number of absorbers and identified a few as giving acceptable Kd values for ${ }^{90} \mathrm{Sr}$ and TRU metals absorption. This work was performed both in cases that did not destroy any complexants present before utilizing the absorber, as well as cases that did perform pretreatment that considerably enhanced the amounts of the metals available for absorption and resulted in much higher $\mathrm{Kd}$ values. Overall, the best $\mathrm{Kd}$ values obtained for metal ion removals with complexants present were obtained with absorbers amorphous hydrous titanium dioxide, two types of proprietary sodium nonatitanate absorbers developed by AlliedSignal, Inc ${ }^{6}$ (sodium nonatitanate (product number $8225-127$ ) and sodium nonatitanate (8104-170)), and potassium hexacyanoferrate crystals as described in LA12943. However, without complexant destruction, none of the absorbers had a sufficient removal efficiency to meet the requirements for the Tank AN-102 and AN-107 supernates.

\subsubsection{Processing Conditions}

Most of the absorbers could be implemented in-tank in compliance with DST operating specifications, if implemented on their own, without thermal pretreatment. However, the $\mathrm{Kd}$ values without pretreatment do not provide sufficient removal efficiency. he thermal pretreatment conditions associated with the absorbers in which the Kd values are optimized may prove to be difficult and possibly too extreme for Hanford tank field conditions. In particular, pretreatment was done at $450{ }^{\circ} \mathrm{C}, 1,500 \mathrm{psi}$ and a contact time of 25 seconds. It is unlikely that these conditions can be engineered in an "in-tank" configuration when all factors associated with a field installation are considered. Installation of the system in a loop configuration "ex-tank" is probably more feasible although there also may be significant engineering issues associated with this configuration.

\subsubsection{Additional Waste Generation}

The additional waste generation would depend on the type of absorber selected. Non-volatile inorganic absorbers may add to the volume of HLW, whereas organic materials will be destroyed under the operating conditions of the melters.

${ }^{6}$ Allied Signal, Inc. is a public corporation headquartered in Morristown, NJ, USA. 


\subsubsection{Schedule Impact}

The absorbers have only been evaluated by laboratory bench-scale testing. They also have not been tested with actual supernate samples from these tanks. The work previously completed on absorbers satisfies some criteria to reach TRLs 1 to 3 , but no level has been fully completed.

The current work being done worldwide indicates a continual, strong interest in applying absorber technology to radioactive waste constituent partitioning. Unfortunately, this review did not discover an application that directly relates to the situation in Tanks AN-102 and AN-107. Materials with Combined Properties have characteristics that are applicable, such as oxidation with absorption, but the technology is not currently advanced enough for implementation at Hanford. It would require substantial development work that could involve a high level of risk to a timely, beneficial outcome.

\subsubsection{Path Forward}

Several constraints and requirements could be evaluated further to assess whether metal ion absorption can be viably implemented in tank farms.

First, the LANL work directed at identifying pretreatment conditions and the best absorbers could be continued along the following lines, using actual wastes:

- Determine the minimum Kd value acceptable for an absorber for each metal ion;

- Determine if the process would be applied "in-tank" or "ex-tank;"

- If "in-tank", determine if pretreatment is feasible;

- If "ex-tank" and pretreatment is required, determine the reaction conditions of temperature, pressure, contact time and feed rate;

- Identify all significant reaction products;

- Identify scale-up testing parameters and perform scale-up testing.

Second, the development work currently being performed worldwide to identify absorbers that could be applicable to AN-102 and AN-107could be continued as follows:

- Contact worldwide investigators to obtain the most up-to-date information and allow for a current review to be made;

- Obtain and evaluate data and information available from the Russian Federation Bochvar Facility (Moscow);

- Perform a worldwide search for other facilities that may have been constructed since the IAEA reports were issued in 2003 and review information and data available from them. 
RPP-RPT-48340, Rev. 0

\subsection{Thermal Processes}

In the nuclear industry, when thermal technologies for processing nuclear wastes are applied to waste pretreatment, they are usually directly linked to an immobilization process. A typical example is a scenario in which a waste immobilization process becomes a two-stage process in which calcination takes place prior to vitrification, as described in LA-UR-94-3174, Hydrothermal Kinetics of Organic and Nitrate/Nitrite Destruction for Hanford Waste Simulant. The application of thermal technologies to waste pretreatment targeted at chemical constituent partitioning such as removal of strontium and TRU metals has not become a standard process in the nuclear industry. However, thermal technology may have a direct application with the supernates of Tanks AN-102 and AN-107 if used to destroy the organic complexants. Thermal technology could cause the insoluble salts of strontium and the TRU metals to precipitate from the alkaline supernates.

\subsubsection{Introduction}

Among the early thermal processes considered were calcining and steam reforming, as detailed in a letter from G.H. Beeman to G. Hansrote, IPM Technology Selection - Final Report. Supercritical water oxidation was also considered (WHC-EP-0365-2, Annual Report of Tank Waste Treatability).

Early work directed at Hanford supernates was performed at LANL in 1994 (LA-UR-94-3174). The organic complexant EDTA was completely destroyed in a simulant comprised of EDTA with sodium nitrate, sodium nitrite and sodium hydroxide. The work was performed in a temperature range of $350-525^{\circ} \mathrm{C}$ and a pressure range of $600-1,200$ bar with a reaction time of less than one minute. Work in parallel with this was performed at Pacific Northwest National Laboratory (PNNL) (PNL-SA-24698, Organic Destruction to Enhance the Separation of Strontium in Radioactive Wastes) but at a lower temperature and pressure. The Tank SY-101 simulant contained EDTA as the organic complexant and was diluted 3:1 with water prior to testing. At a temperature of $365^{\circ} \mathrm{C}$ and a pressure of 250 bar, total organic carbon in the simulant was reduced by $80 \%$.

Following this, a bench-scale evaluation of thermal technology was made in 1995 (WHC-SDWM-TI-719, Preliminary Engineering Evaluation of Heat and Digest Treatment for In-Tank Removal of Radionuclides from Complexed Hanford Tank Waste), with a "low temperatureambient pressure digestion" study using actual wastes from Tanks AN-107 and SY-101. Primary conclusions drawn from this study found that thermal technology could be applied to remove about $60 \%$ of the ${ }^{90} \mathrm{Sr}$, in a four year time period and about $90 \%$ of the TRU metals in a six year time period, if done "in-tank." Also, this study concluded the technology could be applied "extank." Processing conditions suggested included a reaction temperature of $100^{\circ} \mathrm{C}$ with a duration of up to six years. Product gas management would be necessary because nitrous oxide would form in a mixture with the flammable gases hydrogen, ammonia and methane.

No further work after these dates directed at Hanford tank supernates was found. A search of some of the available literature did not identify current applications used in the nuclear industry with similar waste materials. 


\subsubsection{Evaluation}

A definitive reason for not pursuing the use of thermal technology was not identified. However, constraints and requirements of this technology may preclude implementation in the Hanford tank farms. In particular, the elevated temperatures required would be difficult and costly to implement, and it is unclear whether thermal destruction alone would be sufficient to achieve the required decontamination, or whether a supplemental technology such as an absorber would be needed.

\subsubsection{Removal Efficiency}

As described in WHC-SD-WM-TI-719, percent removals of $19 \%$ for ${ }^{90} \mathrm{Sr}$ and $71 \%$ for ${ }^{241} \mathrm{Am}$ were achieved in experiments with actual AN-107 waste (with chemical additions for corrosion control) at a temperature of $100-105^{\circ} \mathrm{C}$ and a duration of 144 days. Performing the same experiment without the chemical adjustment resulted in percent removals of $76 \%$ for ${ }^{90} \mathrm{Sr}$ and $79 \%$ for TRU. The report provides correlations between total organic carbon destruction and removal efficiency, and projects the durations required to achieve higher removal efficiencies.

\subsubsection{Processing Conditions}

The major issues associated with applying thermal technologies to the supernate wastes are the large amounts of heat required and the high temperatures. Secondary issues associated with these technologies include process pressures and product gas mixtures.

\subsubsection{Additional Waste Generation}

Thermal destruction would minimize additional waste generation, as it does not require chemical additions. However, off-gases such as ammonia, hydrogen and methane could be generated from the process.

\subsubsection{Schedule Impact}

Thermal destruction has been tested on both simulants and actual Hanford wastes. The previous work fulfills some of the criteria needed to reach each TRL from 1 to 3 , but no level has been completed.

To achieve an acceptable processing time, it would be necessary to use a high temperature process.

\subsubsection{Path Forward}

Several constraints and requirements could be evaluated to further assess implementation of thermal processes:

- Engineering evaluations/analyses to determine: 
- the highest temperature attainable for thermal degradation both "in-tank" and "ex-tank;"

o the highest pressure attainable for thermal degradation both "in-tank" and "ex-tank;"

o the highest feedstock dilution attainable, if any, for thermal degradation both "in-tank" and "ex-tank."

- Performance of bench-scale testing followed by pilot-scale testing with simulants and actual wastes using the process parameters identified from the prior engineering evaluations/analyses itemized above.

- Preparation of an engineering process flowsheet with associated cost analysis.

\subsection{Advanced Oxidation Processes}

Advanced oxidation processes (AOPs) are "near ambient temperature and pressure water treatment processes which involve the generation of hydroxyl radicals in sufficient quantity to effect water purification" ("The Chemistry of Waster Treatment Processes Involving Ozone, Hydrogen Peroxide, and UV Radiation [Glaze, Kang and Chapin 1987]). Hydroxyl radicals may be formed from the reaction of hydrogen peroxide or ozone with ultraviolet (UV) radiation. The ozone/UV process can produce the hydroxyl radical more efficiently than the hydrogen peroxide/UV process due to the more favorable extinction coefficient of ozone. Hydroxyl radicals can also be formed from ozone at high $\mathrm{pH}$. The hydroxyl free radical is highly reactive and has a high oxidative strength, so it can be expected to readily react with any of the chelates found in the Hanford tank supernate wastes.

\subsubsection{Introduction}

Advanced oxidation processes have been developed extensively for use in the water treatment industry, but their use in the nuclear industry has been more limited. Some of the components of AOP processes have been evaluated for destroying organic complexants at Hanford.

Hydrogen peroxide is a commonly used chemical oxidizer. As explained in Industrial Wastewater Management, Treatment, and Disposal (Water Environment Federation), hydrogen peroxide can be used on its own to oxidize a limited number of compounds, such as aldehydes. However, for compounds that are more difficult to oxidize, it is usually used with a catalyst. The most commonly used catalyst is ferrous ion. This process is called Fenton's reaction, but it is only effective at low $\mathrm{pH}$ whereas the $\mathrm{pHs}$ of Hanford tank wastes are generally high. Hydrogen peroxide oxidation in an acidic medium was considered in WHC-SD-WM-ES-321, In-Tank Processes for Destruction of Organic Complexants and Removal of Selected Radionuclides, as a process for destruction of organic complexants in Hanford tank waste, but was rejected. A basis for this rejection decision was not given in detail, but acidification of the waste may be expected to present several significant obstacles. Many of these obstacles concern the corrosivity of the product wastes as well as hydrogen and other gas generation during the course of the oxidation process. 
Research using hydrogen peroxide in alkaline environments has been limited. A 1995 report, PNL-10766, Removal of Strontium and Transuranics from Hanford Tank Waste via Addition of Metal Cations and Chemical Oxidant - FY 1995 Test Results, describes test results for hydrogen peroxide with a Tank SY-101 simulant: "When hydrogen peroxide was added severe foaming occurred, and the resultant stable foam was three to four times the original volume of the simulant sample. The foam was transferred to another container and appeared to be fairly stable overnight with no agitation. When added to the simulant, the hydrogen peroxide simply decomposed into oxygen and water without oxidizing the organics present. This behavior is typical of hydrogen peroxide when exposed to high $\mathrm{pH}$. Consequently, the use of hydrogen peroxide was eliminated from further consideration." However, in 1997, further research was performed on hydrogen peroxide oxidation in alkaline wastes. PNNL-11623, Investigation on Application of Homogeneous and Heterogeneous Catalysis for Alkaline Waste Treatment, includes a summary of experiments conducted on the oxidation of EDTA using hydrogen peroxide and various metal catalysts. Cobalt was found to be the most effective catalyst, and the maximum destruction of EDTA achieved was $\sim 30 \%$. While this result is of interest, EDTA is not the principal organic species in the tank wastes at this time due to thermal and radioactive degradation over the years of storage in the tanks. Currently, degradation products from EDTA may be the chelates of more significance. As recent analyses have shown, in the Tank AN-107 supernate carboxylate ions such as glycolate and formate are present in much higher concentrations than EDTA or HEDTA (WSRC-TR-2003-00210).

Previous experiments were performed at Hanford using ozonolysis to oxidize organic complexants, as reported in WHC-EP-0701, Laboratory Testing of Ozone Oxidation of Hanford Site Waste from Tank 241-SY-101. While ozonolysis at high $\mathrm{pH}$ has the potential to generate the hydroxyl radical, this report concluded that the high concentration of carbonate in the Tank SY101 waste would consume any hydroxyl radicals that were generated. Thus, other oxidation reactions were responsible for the complexant destruction. It was found that "as expected from known oxidation potentials, ozone quantitatively and preferentially oxidized nitrite ion in test solutions to nitrate ion. Once nitrite oxidation was complete, ozone rapidly and vigorously attacked organic complexants" (WHC-SD-WM-ES-321). This reaction carries a significant disadvantage in terms of tank corrosion, as nitrite inhibits corrosion, while nitrate promotes it. The other major concern raised with ozonolysis was the difficulty of constructing an apparatus to achieve effective contact between the bubbles of ozone and the waste being treated. This factor would be especially problematic if the process were to be implemented in-tank. Due to these factors, ozonolysis was rejected as impractical.

Photolysis with UV light is a process that can be used to break down organic complexants. It requires that the organic components of interest are readily photolyzed, and that the solution being treated allows for sufficient transmission of the UV beam. Compounds in the solution being treated that absorb UV radiation decrease the efficiency of the photolysis process. Nitrites and nitrates absorb UV strongly, and they are present at high levels in the AN-102 and 107 supernate. Photolysis was evaluated in W-236B-PROC-OXI-7, Project $W$-236B Initial Pretreatment Module Pretreatment Process Technology (Photolysis/Ultra Violet Light Oxidation and Advanced Oxidation Technologies). From the results of this evaluation, UV was 
considered to have limited applicability for the destruction of organic complexants in Hanford tank waste. This conclusion was based on the attenuation of the beam in the wastes.

Ultraviolet oxidation with ozone and UV oxidation with hydrogen peroxide were both evaluated for use in the Effluent Treatment Facility, as described in a 1991 report WHC-SD-C018H-TRP002, UV Oxidation Feasibility Test Report in Support of C-018H Effluent Treatment Facility. The study found that $\mathrm{pH}$ adjustment was an important pretreatment step for UV oxidation, and that "the desired $\mathrm{pH}$ range as determined by these tests is between $\mathrm{pH} 5$ to 6 ." A process using UV oxidation with hydrogen peroxide was ultimately recommended.

A combination UV/ozone process currently being developed at SRS is targeted at destroying the oxalic acid used for tank waste heel dissolution in the "Enhanced Chemical Cleaning" process (WSRC-STI-2008-00035, Enhanced Chemical Cleaning: A New Process for Chemically Cleaning Savannah River Waste Tanks - 9100). This process is based on the scale-removal processes used in nuclear power plants. In the future, a variation of it may prove applicable to the organic complexants solvating ${ }^{90} \mathrm{Sr}$ and TRU in Hanford Tank AN-102 and AN-107 supernates. As such, the continuing technical sharing program between Hanford and SRS technical staff may prove to be beneficial.

The combination of UV radiation with ozonolysis has not been studied in conjunction with Hanford activities, although studies have been performed on both UV radiation and ozonolysis application when they are applied separately. In the past, ozone has been considered too corrosive an oxidizer and UV alone has not been found to be sufficiently effective. The SRS work may lead to a workable application for Hanford with these two processes in combination.

\subsubsection{Evaluation}

Advanced oxidation processes are based on chemistry that has been well characterized and successfully applied in many applications. However, application of AOPs to Hanford supernates has potential engineering challenges that have not yet been fully evaluated. One of these challenges is transmission of the UV radiation beam through the wastes. It is possible that the beam will penetration only a limited distance into the waste, rendering the process only amenable to a thin surface layer of waste. If this case occurs, an "ex-tank" engineering application may be required. Also, chemical constraints may exist, including the significant case of the oxidation of nitrite ion to nitrate. If this result occurred, it is possible that sufficient nitrite could be consumed to render the supernate out of specification with the tank waste corrosivity limits. Another chemical constraint is the need to safely control and manage all effluent gases which may include ones that are corrosive or flammable. Finally, AOPs are generally best applied in an acidic environment rather than the basic environment found in the Hanford wastes. This latter item may make the AOP methodology one that cannot be successfully applied at Hanford.

\subsubsection{Removal Efficiency}

The ozonolysis lab testing on actual Tank SY-101 waste showed destruction of $80 \%$ of the organic complexants, and $>99 \%$ removal of ${ }^{90} \mathrm{Sr}$ and ${ }^{241} \mathrm{Am}$ (WHC-EP-0701). It should be noted 
that these were laboratory-scale experiments with optimal mixing of the ozone and the waste solution being treated.

The UV/ozone process being developed for use at SRS was able to achieve greater than $99 \%$ destruction of oxalate (SRR-STI-2010-00015, Enhanced Chemical Cleaning: Effectiveness of the UV Lamp to Decompose Oxalates - 10502). The waste being treated had a high solids concentration, and as the report noted, the decomposition rates were initially fast, but then slowed due to the fouling of the UV lamp. At this point, it appeared that a Fenton's reaction took over, which can produce the hydroxyl radical without UV. However, low $\mathrm{pH}$ is needed for this reaction (the simulant being treated had a $\mathrm{pH}$ of 2). The need for a low $\mathrm{pH}$ may prove to render this method unusable at Hanford unless some suitable variation to it can be developed.

\subsubsection{Processing Conditions}

For UV oxidation to be implemented efficiently, UV radiation must been easily transmitted through the solution being treated, in order to photolyze the ozone. The high levels of nitrite and nitrate in the AN-102 and AN-107 supernate could severely impede the efficiency of a UV oxidation process because they both readily absorb UV radiation. In addition, scale-forming compounds such as calcium salts can cause build-up on the UV lamp. Calcium is present at high levels in the AN-102 and 107 supernate.

There are potential impediments to the application of AOP methods at Hanford.

Notwithstanding potential limitations of transmitting UV radiation through the supernate, ozone can be corrosive to tank wall and ancillary equipment metals. Another factor that can impede UV oxidation is the presence of compounds that can scavenge the hydroxyl radicals, such as the carbonate ion, which is present at high levels in the AN-102 and 107 supernates.

Table 3 compares the concentrations of compounds of interest in the AN-102 and AN-107 supernate to the limits recommended for UV oxidation processes, as detailed in the U.S. Army Corps of Engineers technical letter, ETL-1110-1-161, Engineering and Design:

Ultraviolet/Chemical Oxidation. 
RPP-RPT-48340, Rev. 0

Table 3: Concentrations of Concern for UV Oxidation Processes

\begin{tabular}{|c|c|c|c|}
\hline $\begin{array}{c}\text { Factor Affecting } \\
\text { Treatment }\end{array}$ & $\begin{array}{c}\text { Concentration } \\
\text { of Concern }^{1}\end{array}$ & $\begin{array}{c}\text { AN-102 } \\
\text { Concentration }^{2}\end{array}$ & $\begin{array}{c}\text { AN-107 } \\
\text { Concentration }^{3}\end{array}$ \\
\hline
\end{tabular}

UVInterferences:

\begin{tabular}{|l|r|r|r|}
\hline Nitrate $\left(\mathrm{NO}_{3}{ }^{-}\right)$ & $>10 \mathrm{ppm}$ & $136,000 \mathrm{ppm}$ & $138,000 \mathrm{ppm}$ \\
\hline Nitrite $\left(\mathrm{NO}_{2}{ }^{-}\right)$ & $>10 \mathrm{ppm}$ & $62,000 \mathrm{ppm}$ & $41,000 \mathrm{ppm}$ \\
\hline
\end{tabular}

Hydroxyl Scaveng ers:

\begin{tabular}{|l|r|r|r|}
\hline Chloride $\left(\mathrm{Cl}^{-}\right)$ & $>1000 \mathrm{ppm}$ & $3,000 \mathrm{ppm}$ & $1,000 \mathrm{ppm}$ \\
\hline Nitrate $\left(\mathrm{NO}_{3}{ }^{-}\right)$ & $>10 \mathrm{ppm}$ & $136,000 \mathrm{ppm}$ & $138,000 \mathrm{ppm}$ \\
\hline Carbonates $\left(\mathrm{HCO}_{3}{ }^{-} / \mathrm{CO}_{3}{ }^{-2}\right)$ & $>300 \mathrm{ppm}$ & $50,000 \mathrm{ppm}$ & $54,000 \mathrm{ppm}$ \\
\hline
\end{tabular}

Precipitates:
\begin{tabular}{|l|r|r|r|}
\hline Calcium $\left(\mathrm{Ca}^{+2}\right)$ & $>50 \mathrm{ppm}$ & $300 \mathrm{ppm}$ & $400 \mathrm{ppm}$ \\
\hline
\end{tabular}

1. ETL-1110-1-161, Table A-5

3. RPP-RPT-46772, Rev. 1, Table A-1

2. RPP-RPT-45764, Rev. 0, Table A-1

The high values for these parameters in the Hanford wastes as compared to the recommended limits indicate the challenge the wastes present for applications of AOP methodologies.

\subsubsection{Additional Waste Generation}

Ozone is a gas with limited solubility in aqueous media so that off-gas treatment would be required to destroy the un-reacted ozone. While ozone itself does not add to the volume of HLW, ozone can react with manganese and iron to form insoluble oxides.

\subsubsection{Schedule Impact}

Ozonolysis has been tested for application to Hanford wastes, but UV oxidation with ozone has not been tested. The previous testing of ozonolysis and the application of UV oxidation with ozone at SRS and elsewhere fulfill some of the criteria needed to reach TRLs 1 to 3, but no level has been completed. Any future testing would be directed at the efficacy of removing specific chelates because of the specificity that can be associated with AOP methods.

\subsubsection{Path Forward}

Several constraints and requirements could be evaluated to further assess implementation of AOP processes:

- Engineering evaluations/analyses to determine: 
- Laboratory-scale experiments with different AOP combinations that are targeted at identified major complexant constituents in the wastes to determine the most effective AOP.

- Laboratory-scale experiments on simulants and actual samples of Hanford complexant concentrate waste, to identify the most optimal conditions for using the AOP method identified above.

- Evaluation of the efficacy of the chosen AOP to obtain the basis for "go-no-go" decision making in the application of the AOP for tank AN-102 and AN-107 wastes.

If the activity is to be continued, the follow-on testing could be:

- Performance of bench-scale testing followed by pilot-scale testing using simulants and actual wastes, using the process parameters identified from the prior engineering evaluations/analyses itemized above;

- Preparation of an engineering process flowsheet with associated cost analysis.

\subsection{Filtration}

Filtration is a physical pretreatment method for partitioning waste constituents. It has the primary advantage of not requiring chemical additions, thereby avoiding increasing the overall mass of the waste. However, a challenge often associated with this technology is identifying a filter that does not require considerable operational resources and will not prematurely fail due to clogging.

\subsubsection{Introduction}

Filtration is a mechanical separation process in which ${ }^{90} \mathrm{Sr}$ and TRU metals are removed by passing the supernate through a porous medium that retains them.

Filtration was evaluated in the early $1990 \mathrm{~s}$ as a possible technology for ${ }^{90} \mathrm{Sr}$ and TRU metal removal. It was rejected at that time because there were no filters available that were selective for ${ }^{90} \mathrm{Sr}$ and TRU. This lack of selectivity was a concern because it could lead to a large increase in the volume of HLW glass. This volume increase would occur if compounds having limited allowable loadings in the glass product were retained along with the ${ }^{90} \mathrm{Sr}$ and TRU metal, as described in E/B-SD-W236B-RPT-018, Initial Pretreatment Module Trade Studies, In-Tank Radionuclide Separation.

Seeded ultrafiltration, a process which would use carrier precipitation and ultrafiltration, was also investigated. The preliminary evaluations showed that organic complexants impeded the efficiency of the carrier precipitation, and that colloidal plugging of the filters was often a significant problem (TWRSPP-94-097, Initial Evaluation of Processes Capable of Removing Strontium from Complexant-Containing Alkaline Waste Supernate. FY 1994 Final Report.). 
Recently, excellent advances have been made in filtration technology, and this area continues to be one of great interest in nuclear waste applications, as described in IAEA-TRS-431, Application of Membrane Technologies for Liquid Radioactive Waste Processing. In particular, partitioning of nuclear chemical wastes to remove chemical species such as strontium and actinide metals has received much attention. Nanofilters are able to separate singly-charged ions from multi-charged ions. These could possibly be applied to removing complexed ${ }^{90} \mathrm{Sr}$ and TRU metals (along with multivalent ions) from the supernate while leaving behind sodium and other monovalent ions. Ultrafilters are able to remove colloidal suspensions and heavy molecular weight chemical species (i.e. those with atomic weights greater than about 200 atomic mass units) from solution. Thus, ultrafilters are ideal for preparing feed stock for nanofilters, while nanofilters could be used for final polishing to remove ${ }^{90} \mathrm{Sr}$ and TRU metals.

In the nuclear industry, nanofilters have been applied to chemical wastes for ${ }^{90} \mathrm{Sr}$ and $\mathrm{TRU}$ partitioning, but with feedstocks much more dilute in total dissolved solids than the AN-102 and AN-107 supernates (IAEA-TRS-431). These feedstocks have contained concentrations of dissolved solids of about 40,000 parts per million (ppm), whereas the supernates in Tanks AN102 and AN-107 contain about 500,000 ppm dissolved solids. A search of some of the current literature did not identify nano or ultra filters that have been applied to solutions with physical and chemical concentration characteristics similar to those of the AN-102 and AN-107 supernates.

\subsubsection{Evaluation}

This review did not identify a definitive reason for not pursuing the use of filters. However, more studies and evaluations are needed to identify the specific method to be applied and establish the means of implementation. The risk of such an undertaking is high because of the current level of technological development of filtration systems. An application of filtration to nuclear wastes very similar to those in Tanks AN-102 and AN-107 was not found during the course of this review. Even though an application is not yet available for tank wastes, the concept will remain of interest because it offers a means of waste partitioning without adding more materials to the wastes.

Nanofilters offer promise because they can partition singly-charged ions from multi-charged ones. As such, ${ }^{90} \mathrm{Sr}$ and TRU metal ions can be removed from the bulk of the wastes, albeit with other multi-charged ions. New developmental work is needed to determine how to further separate the multi-charged ion part of the waste to isolate ${ }^{90} \mathrm{Sr}$ and the TRU metal ions. This separation would allow the ${ }^{90} \mathrm{Sr}$ and TRU metal ions to be added to the HLW without unduly increasing the volume by adding all the other multi-charged ions. The risk of not obtaining a successful outcome in this developmental work adds to the burden of pursuing filtration as an applicable technology.

Filtration processes inherently contain the challenge of operating the filters so that they remain functional. Development work to obtain operations procedures has not been addressed. 


\subsubsection{Removal Efficiency}

As reported in the literature, nanofilters that would be selective for complexed strontium and TRU metals as well as other multi-valent ions are available. However, their removal efficiencies in AN-102 and AN-107 wastes have not been evaluated even on a laboratory-scale.

\subsubsection{Processing Conditions}

The performance conditions and compatibility of the filters with the AN-102 and AN-107 wastes has not yet been established by testing. A reduction in operability could result from fouling or plugging of the filters. Operability is always an issue for filtration, requiring procedures to be in place to periodically clean the filters to assure sufficient performance of the equipment. Anti-fouling operations requirements and procedures also have not been established by testing.

\subsubsection{Additional Waste Generation}

Filtration is a physical process in which, unless incorporated in a "combination process," no materials are added to the waste. However, the volume of HLW could be increased by partitioning of other multi-valent ions besides ${ }^{90} \mathrm{Sr}$ and TRU to the solid waste.

\subsubsection{Schedule Impact}

Ultrafiltration has been tested for use with Hanford waste, and it is the planned technology for solid/liquid separation in the WTP pretreatment facility. On the other hand, nanofiltration has been used in various industrial applications, but has not been tested on simulants or actual Hanford waste. Thus, some of criteria needed to reach TRLs 1 and 2 have been fulfilled, but neither of the levels has been completed.

The precise processing time required for filtration has not been determined. To establish this timing, filters need to be identified that can give sufficient flow rates so that the supernates can be filtered in an acceptable time frame. The flow rate is related to the membrane permeability for the dissolved chemical species, which is in turn related to the diffusion coefficients and the matter partition coefficients of the dissolved species. It is also related to the thickness of the filter.

\subsubsection{Path Forward}

Several constraints and requirements could be evaluated to further assess implementation of filtration as a viable technology for partitioning strontium and the TRU metals in the AN-102 and AN-107 supernates. Primarily, application of this technology may not be feasible due to operations requirements or mass transport limitations through the filters.

Actions that could be taken to further develop this technology are: 
- Perform a cost-to-benefit risk analysis on the implementation of technical feasibility studies;

- Continue the search for filters that are sufficiently permeable to the supernates;

- If such filters are found, bench test them;

- Prepare a flowsheet and associated operations procedures for filter flushing and cleaning.

\subsection{Electrochemical Destruction}

Electrochemical processes are widely used in the chemical industry, but have limited application in treatment of nuclear waste. In an electrochemical destruction process, electric current would be passed through the waste between a cathode and an anode. For Hanford purposes, this technology would be targeted to destructively oxidize the organic complexants at the anode.

As stated in the 1994 report, WHC-SA-2478-FP, Status of Test Results of Electrochemical Organic Oxidation of a Tank 241-SY-101 Simulated Waste: "Minimal development work has been applied to alkaline electrochemical organic destruction. Most electrochemical work has been directed towards acidic electrolysis as in the metal purification industry and silver catalyzed oxidation. Alkaline electrochemistry has traditionally been associated with the following: (1) inefficient power use, (2) electrode fouling, and (3) solids handling problems."

\subsubsection{Introduction}

The electrochemical destruction process initially considered utilized cells that would require acidification of the waste with nitric acid. This process was rejected, as detailed in WHC-EP0365-2, due to the "increases in waste volume that are associated with acidification and subsequent re-neutralization of the waste."

Subsequent work on electrochemical oxidation is described in PNL-10131, Electrochemical Organic Destruction in Support of Hanford Tank Waste Pretreatment. Several types of anode materials, such as platinized titanium and tin oxide, were tested with a simulant of complexant concentrate waste. The process was monitored by observing the destruction of EDTA. The platinized titanium anode was the best performer, showing the highest organic destruction efficiency without fouling. Tests were performed at temperatures ranging from $30^{\circ} \mathrm{C}$ to $90^{\circ} \mathrm{C}$, with the best destruction efficiency seen at $50^{\circ} \mathrm{C}$. Tests were performed with a bench-scale flow cell, and then with an engineering-scale flow cell. Higher destruction efficiency was seen with the engineering-scale flow cell, which was attributed to better mass transfer from the higher flow rate and higher turbulence.

Testing with a pilot-scale electrochemical flow cell using simulants of Hanford and SRS LAW is described in WSRC-TR-95-0405, Final Report on the Large Scale Demonstration for the Electrochemical Processing Hanford and Savannah River Site High-Level Waste Simulants.

The testing on Hanford waste simulant was performed with divided and undivided cell configurations and a platinized titanium anode. The temperature was $65^{\circ} \mathrm{C}$, and the circulation 
rate was 4-4.5 gallons per minute ( $\mathrm{gal} / \mathrm{min}$ ). During 40 hours of testing, the undivided cell destroyed $77 \%$ of the organic complexants, and the divided cell destroyed $22 \%$. In the undivided configuration all of the nitrite was oxidized to nitrate.

Testing with simulated and actual wastes from Tank SY-101 is described in PNNL-11590, Electrochemical Destruction of Organics and Nitrates in Simulated and Actual Radioactive Hanford Tank Waste. The test periods were four hours and a platinized titanium anode was used. The results for simulant were similar to the pilot-scale testing in WSRC-TR-95-0405, but with lower nitrite ion reduction. However, the destruction of organic complexants was much lower in the actual SY-101 waste than in the simulated waste. It was noted that this result could be due in part to the difference in organic species present in the simulant versus the actual waste. EDTA was the only organic species in the simulant, while the actual waste contained a variety of organic species. Further testing on actual waste was recommended, with test periods of 50 to 100 hours.

Subsequently, research into anode materials for electrochemical oxidation was conducted at the University of Wisconsin and the California Institute of Technology from 1996 to 2000 in a project for the DOE EM Science Program (DOE/ER/14725, Investigation of Novel Electrode Materials for Electrochemically-Based Remediation of High-and Low-Level Mixed Wastes in the DOE Complex - Final Report). The studies hoped to find a material that would have a low efficiency for water oxidation and a higher efficiency for organic oxidation. Titanium oxide with various dopants was the primary material investigated. This work was focused on anode development, and did not proceed to testing on waste simulants.

A 2000 article summarizing electrochemical destruction research for DOE and the Department of Defense identifies the reports previously described (PNL-10131, WSRC-TR-95-0405, PNNL11590, and DOE/ER/14725) but does not list any recent research ("Electrochemical Treatment and Minimization of Defense-Related Wastes" [Pillay 2000]). More recent research into relevant applications of electrochemical destruction for organic constituents in nuclear waste has not been discovered in this review.

\subsubsection{Evaluation}

This review did not identify a definitive reason for not pursuing the use of electrochemical technology. However, constraints and requirements of this technology may preclude implementation in the Hanford tank farms.

\subsubsection{Removal Efficiency}

Further work would be required to determine the removal efficiency of an electrochemical destruction process. Most of the testing at Hanford focused on the destruction of organic complexants as an end in itself, not specifically on the removal of ${ }^{90} \mathrm{Sr}$ and TRU. WSRC-TR95-0405 reports organic destruction of up to $77 \%$ for a simulant solution. 


\subsubsection{Processing Conditions}

If implemented, the electrochemical processes tested would probably be performed ex-tank in an electrochemical cell. The major issues associated with applying electrochemical technologies to the supernate wastes concern the operability and efficiency of the electrochemical cell. Fouling of the electrodes is one of the main challenges. The non-selectivity of electrochemical destruction is also a challenge. Nitrite can be oxidized to nitrate, which presents problems in terms of tank corrosion.

\subsubsection{Additional Waste Generation}

An electrochemical process does not require chemical additions, so additional waste generation would be minimal. However, flammable off-gases such as hydrogen and ammonia may be generated.

\subsubsection{Schedule Impact}

Electrochemical destruction has been tested with both simulants and actual Hanford waste. Some of the criteria needed to reach TRLs 1 to 3 have been fulfilled, but no level has been completed.

\subsubsection{Path Forward}

Several constraints and requirements could be evaluated to further assess implementation of electrochemical processes:

- Engineering evaluations/analyses to determine the level of efficiency needed to make electrochemical destruction a technically and economically practicable process;

- Further laboratory optimization testing on specific anodes for current efficiency and corrosion resistance;

- Performance of bench-scale testing followed by pilot-scale testing using simulants and actual wastes using the process parameters identified from the prior engineering evaluations/analyses itemized above;

- Preparation of an engineering process flowsheet with associated cost analysis.

\subsection{Solvent Extraction}

A solvent extraction process would partition the ${ }^{90} \mathrm{Sr}$ and TRU to a solvent that can be separated from the remainder of the supernate. Solvent extraction processes have a long history in the nuclear industry. The fuel reprocessing methods used at Hanford included several types of solvent extraction processes. Solvent extraction was also used to remove ${ }^{90} \mathrm{Sr}$ and cesium $\left({ }^{137} \mathrm{Cs}\right)$ from the tank waste for storage in capsules. 


\subsubsection{Introduction}

The strontium extraction (SREX) and transuranium extraction (TRUEX) processes were considered for ${ }^{90} \mathrm{Sr}$ and TRU removal from complexant-containing waste, as described in PNL8438, Exploratory Study of Complexant Concentrate Waste Processing. The cobalt dicarbolide and di-(2-ethylhexyl) phosphoric acid processes were also investigated, as described in PNL9053, Review and Assessment of Technologies for the Separation of Strontium from Alkaline and Acidic Media. All of these processes were developed for use on acidified waste, although the potential to research their use in alkaline waste was noted (PNL-9053).

Some experiments were performed using solvent extraction in alkaline environments. A process using dicyclohexano-18-crown-6 and a high molecular weight neocarboxylic acid was effective for removing ${ }^{90} \mathrm{Sr}$ from alkaline solutions, but the removal efficiency was greatly decreased by the presence of organic complexants (PNL-8438). A process using alkylated catechol derivatives was investigated for extraction of americium from alkaline solution, but again, the presence of organic complexants decreased the removal efficiency substantially (PNL-8438).

WSRC-TR-2000-00229, Evaluation of Alternate Methods for Strontium and Alpha Removal from Savannah River Site High Level Waste Solutions provides a review of these and other alkaline solvent extraction processes, such as an alkaline cobalt dicarbolide process (as well as other strontium and TRU removal technologies), although the efficacy in the presence of organic complexants for the cobalt dicarbolide process is not noted.

Solvent extraction does not appear to be a major area of current research for ${ }^{90} \mathrm{Sr}$ and TRU removal.

\subsubsection{Evaluation}

This review did not identify a definitive reason for not pursuing the use of solvent extraction technology. However, constraints and requirements of this technology may preclude implementation in the Hanford tank farms.

\subsubsection{Removal Efficiencies}

Excellent removal efficiencies (over 90\%) were seen with acidic processes, but alkaline processes did not perform as well (E/B-SD-W236B-RPT-018).

\subsubsection{Processing Conditions}

Acidic solvent extraction processes are not compatible with the alkaline chemistry of the AN102 and $\mathrm{AN}-107$ waste.

\subsubsection{Additional Waste Generation}

The acidification and neutralization of the waste for an acidic solvent extraction processes would increase the waste volume significantly. The addition of water to the waste as a result of the 
chemical addition steps required in solvent extraction would require an evaporation process. The chemical additions would also increase the mass of the immobilized waste product.

\subsubsection{Schedule Impact}

Acidic solvent extraction processes have been extensively tested, and used in full-scale applications. However, alkaline processes are still in the stage of laboratory-scale testing, and their feasibility is not yet proven. The work on alkaline solvent extraction processes fulfills some of the criteria needed to reach TRLs 1 to 3 , but no level has been completed.

\subsubsection{Path Forward}

Several constraints and requirements could be evaluated to further assess implementation of solvent extraction processes:

- Engineering evaluations/analyses to optimize process parameters;

- Performance of bench-scale testing followed by pilot-scale testing with simulants and actual wastes using the process parameters identified from the prior engineering evaluations/analyses itemized above;

- Preparation of an engineering process flowsheet with associated cost analysis. 


\subsection{DOWN-SELECTION OF ALTERNATIVES}

The alternative processes were evaluated using a method from RPP-RPT-32300, Demonstration Bulk Vitrification System Value Engineering Report. The four criteria used were weighted, as shown in Appendix B. The alternatives were then ranked against each criterion, and a weighted score was calculated. The results are shown in Table 4.

Table 4: Matrix Weighting of Alternatives

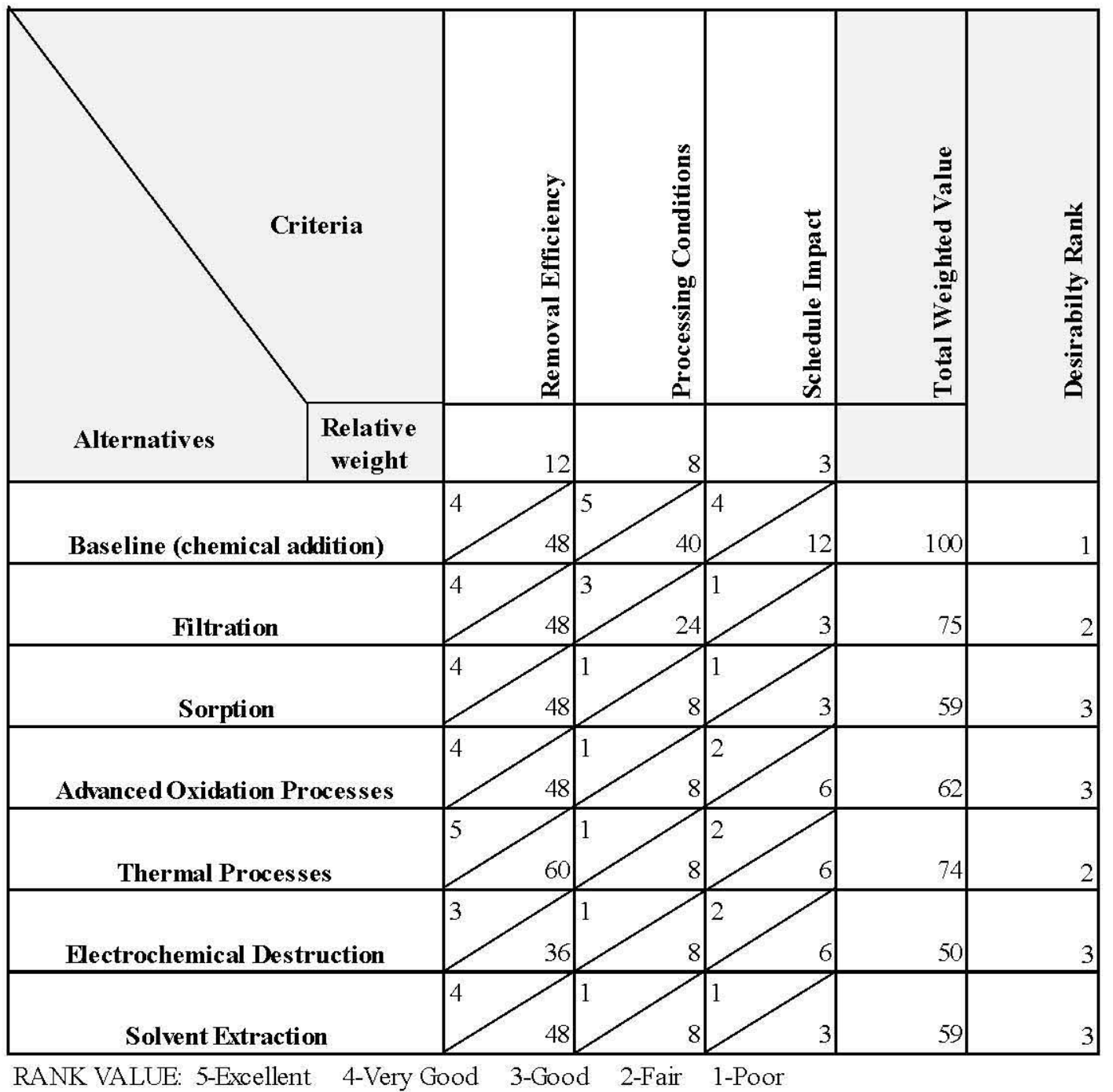

The values in Table 4 are based on engineering judgment. Absolute objective values are not available because of the limited TRL assessments associated with each of the processes, except for solvent extraction which has an in-depth operating history at the Hanford Site. Nevertheless, the planned baseline process of isotopic dilution of ${ }^{90} \mathrm{Sr}$ combined with permanganate oxidation of the chelates ranks significantly higher than any of the other processes. The down-selection 
method used gives a wide range in the "Weighted Scores" from a high value of 100 to a low value of 50, so that the criteria used yielded good selectivity among the processes. Given that the down-selection judgments are somewhat subjective, the "Ranking" values were placed in just three ratings. The highest rating was given to the baseline process; the lowest rating was given to electrochemical destruction, advanced oxidation processes, sorption, and solvent extraction; and filtration and thermal destruction were placed in the middle group.

One of the original four criteria, "Additional Waste Generation," dropped out during the weighting process, as it was not rated as being more important than any of the other criteria. However, it can still be discussed in terms of the advantages and disadvantages of the alternatives. The baseline process, which received the highest ranking, includes chemical additions that would increase the mass of HLW. While some of the alternative processes have the potential to generate less waste, the difference in waste generation was not significant enough to override the TRL or removal efficiency rankings. 
RPP-RPT-48340, Rev. 0

\subsection{CONCLUSIONS AND RECOMMENDATIONS FOR FUTURE WORK}

This review supports implementation of in-tank precipitation with strontium nitrate and sodium permanganate to remove ${ }^{90} \mathrm{Sr}$ and TRU from the AN-102 and AN-107 supernate.

The processes included in this review were:

- Baseline (chemical addition);

- Filtration;

- Sorption;

- Advanced Oxidation Processes;

- Thermal Processes;

- Electrochemical Destruction;

- Solvent Extraction.

The down-selection methodology used to rank the processes used criteria that were numerically weighted based on engineering opinion after an extensive review of available, current information and data. The planned baseline process was significantly more highly rated than any of the other processes.

The testing and evaluations that are applicable to the strontium nitrate/sodium permanganate process were targeted at performing the chemical additions in the WTP with waste that was diluted to a 5.5 molar sodium ion concentration, along with a final filtration step. In all probability, these two conditions will not apply to adding the strontium nitrate/sodium permanganate in-situ in tank farms. It may not be necessary or even beneficial to dilute the waste from the approximately 9 molar sodium ion concentration existing in the tanks at this time. It also may not be necessary to physically separate the supernate after the chemical additions, but only to allow the product precipitate to drop out of the supernate and into the solid waste.

Other factors may need further testing and evaluation to ensure the process can be performed robustly in-situ in tank farms. These factors include determining the stability of the product solids formed, gaining more understanding of required mixing conditions, and determining the best conditions for precipitate formation and removal from the supernate. Hence, the process may not yet have reached a TRL for large scale testing. 
RPP-RPT-48340, Rev. 0

\subsection{REFERENCES}

10 CFR 61, "Licensing Requirements for Land Disposal of Radioactive Waste," Code of Federal Regulations, as amended.

12110-PCL94-026, 1994, "Strontium Removal by Precipitation," (internal memorandum from D. L. Herting to M. J. Klem, March 28), Westinghouse Hanford Company, Richland, Washington.

7G330-MEJ-04-003, 2004, "Re-assessment of Need to Remove Transuranic Elements from Tanks 241-AY-101, 241-AN-102, and 241-AN-107 Low Activity Waste Fraction," (internal letter from M. E. Johnson to R. Ni, April 8), CH2M Hill Hanford Group, Inc., Richland, Washington.

7S110-RWW-05-017, 2005, "Test Results for At-Tank Conditions for Strontium/Transuranic Removal from Tank 241-AN-107 Supernatant," (internal memorandum from R.W. Warrant to M. E. Johnson, May 9), CH2M Hill Hanford Group, Inc., Richland, Washington.

BNF-003-98-0171, 2000, Investigation of Varied Strontium-Transuranic Precipitation Chemistries for Crossflow, Rev. 0, Westinghouse Savannah River Company, Aiken, South Carolina.

Cotton, A.F., and G. Wilkinson, 1980, Advanced Inorganic Chemistry, A Comprehensive Text, Fourth Edition, John Wiley \& Sons, New York, New York.

DOE. 2008, Technology Readiness Assessment (TRA) / Technology Maturation Plan (TMP) Process Guide, U.S. Department of Energy, Office of Environmental Management, Washington, D.C.

DOE/ER/14689 (Project Number 54735), 2000, Cesium and Strontium Specific Exchangers for Nuclear Waste Effluent Remediation - Final Report, U.S. Department of Energy, Office of Environmental Management, Washington, D.C.

DOE/ER/14725 (Project Number 55137), 2000, Investigation of Novel Electrode Materials for Electrochemically-Based Remediation of High-and Low-Level Mixed Wastes in the DOE Complex - Final Report, U.S. Department of Energy, Washington, D.C.

DOE/ER/62313 (Project Number 55146), 1999, Adsorption/Membrane Filtration as a Contaminant Concentration and Separation Process for Mixed Wastes and Tank Wastes - Final Report, U.S. Department of Energy, Washington, D.C.

DOE M 435.1 Chg 1, 2001, Radioactive Waste Management Manual, U.S. Department of Energy, Washington, D.C. 
E/B-SD-W236B-RPT-018, 1995, Initial Pretreatment Module Studies: In-Tank Radionuclide Separation, Rev. 1, Raytheon/BNFL, Richland, Washington.

ETL 1110-1-161, 1996, Engineering and Design: Ultraviolet/Chemical Oxidation, Department of the Army, U.S. Army Corps of Engineers, Washington, D.C.

Felmy, A. R., and M. J. Mason, 1998, "The Displacement of Sr from Organic Chelates by Hydroxide, Carbonate, and Calcium in Concentrated Electrolytes," Journal of Solution Chemistry, Vol. 27, No. 5, pp. 435-454.

Glaze, W. H., Kang, J. W. \& Chapin, D. H. 1987, "The Chemistry of Water Treatment Processes Involving Ozone, Hydrogen Peroxide and UV-Radiation," Ozone: Science \& Engineering, Vol. 9, Issue 4, pp 335-352.

IAEA-TECDOC-1336, 2003, Combined Methods for Liquid Radioactive Waste Treatment, International Atomic Energy Agency, Vienna, Austria.

IAEA-TRS-431, 2004, Application of Membrane Technologies for Liquid Radioactive Waste Processing, International Atomic Energy Agency, Vienna, Austria.

LA-12654, 1993, Distributions of 14 Elements on 60 Absorbers from Two Simulant Solutions (Acid-Dissolved Sludge and Alkaline Supernate) for Hanford HLW Tank 102-SY, Los Alamos National Laboratory, Los Alamos, New Mexico

LA-12862, 1995, Effects of Aqueous-Soluble Organic Compounds on the Removal of Selected Radionuclides from High-Level Waste Part I: Distribution of Sr, Cs, and Tc onto 18 Absorbers from an Irradiated, Organic-Containing Leachate Simulant for Hanford Tank 101-SY, Los Alamos National Laboratory, Los Alamos, New Mexico.

LA-12863, 1994, Distributions of 15 Elements on 58 Absorbers from Simulated Hanford Double-Shell Slurry Feed (DSSF), Los Alamos National Laboratory, Los Alamos, New Mexico.

LA-12943, 1995, Effects of Soluble Organic Complexants and Their Degradation Products on the Removal of Selected Radionuclides from High-Level Waste Part II: Distributions of Sr, Cs, Tc and Am onto 32 Absorbers from Four Variations of Hanford Tank 101-SY Simulant Solution, Los Alamos National Laboratory, Los Alamos, New Mexico.

LA-13000, 1995, Effects of Soluble Organic Complexants and Their Degradation Products on the Removal of Selected Radionuclides from High-Level Waste Part III: Distributions of Sr, Cs, Tc, Pu and Am onto 33 Absorbers from Four Variations of a 3:1 Dilution of Hanford Complexant Concentrate (CC) Simulant Solution, Los Alamos National Laboratory Los Alamos, New Mexico.

LA-UR-94-3174, 1994, Hydrothermal Kinetics of Organic and Nitrate/Nitrite Destruction for Hanford Waste Simulant, Los Alamos National Laboratory, Los Alamos, New Mexico. 
Letter, C. J. Paperiello, Office of Nuclear Material Safety and Safeguards, U.S. Nuclear Regulatory Commission, to J. Kinzer, U.S. Department of Energy, Richland Operations Office, Richland, Washington, Classification of Hanford Low-Activity Tank Waste Fraction, June 9, 1997.

Letter, G.H. Beeman, Pacific Northwest Laboratories, to G. Hansrote, Westinghouse Hanford Co., Richland, Washington, IPM Technology Selection - Final Report, June 15, 1993.

Letter, R. M. Bernero, Office of Nuclear Material Safety and Safeguards, U.S. Nuclear Regulatory Commission, to J. Lytle, U.S. Department of Energy, Office of Waste Management, Washington D.C., March 2, 1993.

ORP-11242, 2010, River Protection Project System Plan, Rev. 5, U.S. Department of Energy, Office of River Protection, Richland, Washington.

OSD-T-151-00007, 2010, Operating Specifications for the Double-Shell Storage Tanks, Rev. 5, Washington River Protection Solutions, LLC, Richland, Washington.

Pillay, G., et al, 2000, "Electrochemical Treatment and Minimization of Defense-Related Wastes," Federal Facilities Environmental Journal, Vol.11, Issues 22, pp. 115-127.

PNL-10131, 1994, Electrochemical Organic Destruction in Support of Hanford Tank Waste Pretreatment, Pacific Northwest Laboratory, Richland, Washington.

PNL-10766, 1995, Removal of Strontium and Transuranics from Hanford Tank Waste via Addition of Metal Cations and Chemical Oxidant - FY 1995 Test Results, Pacific Northwest Laboratory, Richland, Washington.

PNL-8438, 1993, Exploratory Study of Complexant Concentrate Waste Processing, Pacific Northwest Laboratory, Richland, Washington.

PNL-9053, 1994, Review and Assessment of Technologies for the Separation of Strontium from Alkaline and Acidic Media, Pacific Northwest Laboratory, Richland, Washington.

PNL-SA-24698, 1994, Organic Destruction to Enhance the Separation of Strontium in Radioactive Wastes, Pacific Northwest Laboratory, Richland, Washington.

PNNL-11480, 1997, Speciation of Organic Carbon in Hanford Waste Storage Tanks: Part 1, Pacific Northwest National Laboratory, Richland, Washington.

PNNL-11590, 1996, Electrochemical Destruction of Organics and Nitrates in Simulated and Actual Radioactive Hanford Tank Waste, Pacific Northwest National Laboratory, Richland, Washington. 
PNNL-11623, 1997, Investigation on Application of Homogeneous and Heterogeneous Catalysis for Alkaline Waste Treatment, Pacific Northwest National Laboratory, Richland, Washington.

PNWD-3340, 2003, Assessment of Sr/TRU Removal Mechanisms Using AN-102 and AN-107 Tank Waste Samples, Rev. 0, Pacific Northwest National Laboratory, Richland Washington.

RPP-17152, 2010, Hanford Tank Waste Operations Simulator (HTWOS) Version 6.O Model Design Document, Rev. 4, Washington River Protection Solutions, LLC, Richland, Washington.

RPP-24809, 2005, Strontium and TRU Separation Process in the DST System, Rev. 0, CH2M Hill Hanford Group, Inc., Richland, Washington.

RPP-RPT-32300, 2007, Demonstration Bulk Vitrification System Value Engineering Report, Rev. 0, Washington River Protection Solutions, LLC, Richland, Washington.

RPP-RPT-45764, 2010, Derivation of Best-Basis Inventory for Tank 241-AN-102, Rev. 0, Washington River Protection Solutions, LLC, Richland, Washington.

RPP-RPT-46772, 2010, Derivation of Best-Basis Inventory for Tank 241-AN-107, Rev. 1, Washington River Protection Solutions, LLC, Richland, Washington.

SRNL-STI-2008-00426, 2008, The Role of Liquid Waste Pretreatment Technologies in Solving the DOE Clean-Up Mission, Savannah River National Laboratory, Aiken, South Carolina.

SRR-STI-2010-00015, 2010, Enhanced Chemical Cleaning: Effectiveness of the UV Lamp to Decompose Oxalates - 10502, Savannah River Remediation, Aiken, South Carolina.

SVF-1922, 2010, "Transfers_MMR-10-032-JHF-2-GKA-5.4-8.4r0-2010-07-14-at-23-5505.xlsm," Rev. 0, Washington River Protection Solutions LLC, Richland, WA.

TWRSPP-94-097, 1994, Initial Evaluation of Processes Capable of Removing Strontium from Complexant-Containing Alkaline Waste Supernate. FY 1994 Final Report. Westinghouse Hanford Company, Richland, Washington.

W-236B-PROC-OXI-7, 1992, Project W-236B Initial Pretreatment Module Pretreatment Process Technology (Photolysis/Ultra Violet Light Oxidation and Advanced Oxidation Technologies), Kaiser Engineers Hanford, Richland, Washington.

Water Environment Federation, 2008, Industrial Wastewater Management, Treatment, and Disposal, Third edition, McGraw-Hill Professional, New York, New York. 
WHC-EP-0365-2, 1992, Annual Report of Tank Waste Treatability, Westinghouse Hanford Company, Richland, Washington.

WHC-EP-0701, 1993, Laboratory Testing of Ozone Oxidation of Hanford Site Waste from Tank 241-SY-101, Rev. 0, Westinghouse Hanford Company, Richland, Washington.

WHC-SA-2478-FP, 1994, Status of Test Results of Electrochemical Organic Oxidation of a Tank 241-SY-101 Simulated Waste, Westinghouse Hanford Company, Richland, Washington.

WHC-SD-C018H-TRP-002, 1991, UV Oxidation Feasibility Test Report in Support of C-018H Effluent Treatment Facility, Rev. 0, Westinghouse Hanford Company, Richland, Washington.

WHC-SD-WM-ES-321, 1995, In-Tank Processes for Destruction of Organic Complexants and Removal of Selected Radionuclides, Rev. 0, Westinghouse Hanford Company, Richland, Washington.

WHC-SD-WM-TI-699, 1996, Technical Basis for Classification of Low-Activity Waste Fraction from Hanford Site Tanks, Rev.2, Westinghouse Hanford Company, Richland, Washington.

WHC-SD-WM-TI-719, 1995, Preliminary Engineering Evaluation of Heat and Digest Treatment for In-Tank Removal of Radionuclides from Complexed Hanford Tank Waste, Rev. 0, Westinghouse Hanford Company, Richland Washington.

WSRC-STI-2008-00035, 2009, Enhanced Chemical Cleaning: A New Process for Chemically Cleaning Savannah River Waste Tanks - 9100, Rev. 1, Washington Savannah River Company, Aiken, South Carolina.

WSRC-TR-2000-00229, 2000, Evaluation of Alternate Materials and Methods for Strontium and Alpha Removal from Savannah River Site High-Level Waste Solutions, Westinghouse Savannah River Company, Aiken, South Carolina.

WSRC-TR-2003-00204, 2003, Final Report: Pilot-Scale Cross-Flow Ultrafiltration Test Using a Hanford Site Tank 241-AN-102 Waste Simulant (U), Rev. 0, Westinghouse Savannah River Company, Aiken, South Carolina.

WSRC-TR-2003-00210, 2003, Compositing, Homogenization and Characterization of Samples from Hanford Tank 241-AN-107. Rev.0, Westinghouse Savannah River Company, Aiken, South Carolina.

WSRC-TR-95-0405, 1995, Final Report on the Large Scale Demonstration for the Electrochemical Processing Hanford and Savannah River Site High-Level Waste Simulants, Westinghouse Savannah River Company, Aiken, South Carolina. 
RPP-RPT-48340, Rev. 0

\section{APPENDIX A: CALCULATION OF REMOVAL EFFICIENCY}

Table A-1. Selected Tank Constituents

\begin{tabular}{|c|c|c|c|}
\hline \multicolumn{2}{|r|}{ Constituent } & AN-102* & $\mathrm{AN}-107 * *$ \\
\hline \multicolumn{2}{|c|}{$\mathrm{Na}(\mathrm{kg})$} & $7.21 \mathrm{E}+05$ & $6.77 \mathrm{E}+05$ \\
\hline \multicolumn{2}{|c|}{$90 \mathrm{Sr}(\mathrm{Ci})$} & $2.26 \mathrm{E}+05$ & $2.30 \mathrm{E}+05$ \\
\hline \multicolumn{2}{|c|}{ TRU(Ci) } & $5.28 \mathrm{E}+02$ & $3.18 \mathrm{E}+03$ \\
\hline \multirow{11}{*}{ 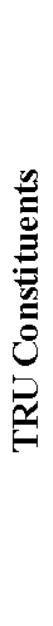 } & $237 \mathrm{~Np}(\mathrm{Ci})$ & $4.09 \mathrm{E}-01$ & $1.87 \mathrm{E}-01$ \\
\hline & $238 \mathrm{Pu}(\mathrm{Ci})$ & $4.99 \mathrm{E}+00$ & $1.05 \mathrm{E}+01$ \\
\hline & $239 \mathrm{Pu}(\mathrm{Ci})$ & $1.76 \mathrm{E}+01$ & $1.49 \mathrm{E}+02$ \\
\hline & $240 \mathrm{Pu}(\mathrm{Ci})$ & $4.56 \mathrm{E}+00$ & $3.87 \mathrm{E}+01$ \\
\hline & $241 \mathrm{Am}(\mathrm{Ci})$ & $4.32 \mathrm{E}+02$ & $2.40 \mathrm{E}+03$ \\
\hline & $241 \mathrm{Pu}(\mathrm{Ci})$ & $6.62 \mathrm{E}+01$ & $5.61 \mathrm{E}+02$ \\
\hline & $242 \mathrm{Cm}(\mathrm{Ci})$ & 8.33E-01 & $9.01 \mathrm{E}+00$ \\
\hline & $242 \mathrm{Pu}(\mathrm{Ci})$ & $4.83 \mathrm{E}-04$ & $4.10 \mathrm{E}-03$ \\
\hline & 243Am (Ci) & $2.84 \mathrm{E}-01$ & $1.58 \mathrm{E}+00$ \\
\hline & $243 \mathrm{Cm}(\mathrm{Ci})$ & $4.26 \mathrm{E}-02$ & $2.37 \mathrm{E}-01$ \\
\hline & $244 \mathrm{Cm}(\mathrm{Ci})$ & $9.51 \mathrm{E}-01$ & $5.29 \mathrm{E}+00$ \\
\hline
\end{tabular}

*RPP-RPT-45764, Derivation of Best-Basis

Inventory for Tank 241-AN-102, Rev. 0

**RPP-RPT-46772, Derivation of Best-Basis

Inventory for Tank 241-AN-107, Rev.1

Sodium Loading in Glass

$$
\begin{gathered}
\left(0.2 \frac{\mathrm{kg} \mathrm{Na}}{\mathrm{kg} \mathrm{glass}}\right)\left(\frac{1 \mathrm{kmol} \mathrm{Na}_{2} \mathrm{O}}{62 \mathrm{~kg} \mathrm{Na} \mathrm{O}_{2} \mathrm{O}}\right)\left(\frac{2 \mathrm{kmol} \mathrm{Na}}{1 \mathrm{kmol} \mathrm{Na} \mathrm{N}_{2} \mathrm{O}}\right)\left(\frac{23 \mathrm{~kg} \mathrm{Na}}{1 \mathrm{kmol} \mathrm{Na} a_{2} \mathrm{O}}\right) \\
=0.15 \frac{\mathrm{kg} \mathrm{Na}}{\mathrm{kg} \mathrm{glass}}
\end{gathered}
$$

Removal Efficiency

$$
\text { Removal Ef ficiency }(\%)=\left(1-\frac{\text { Desired concentration in glass }}{\text { Original concentration in glass }}\right) 100
$$


RPP-RPT-48340, Rev. 0

\section{AN-102}

Mass of glass made from supernate

$$
\left(7.21 \times 10^{5} \mathrm{~kg} \mathrm{Na}\right)\left(\frac{1 \mathrm{~kg} \text { glass }}{0.15 \mathrm{~kg} \mathrm{Na}}\right)=4.86 \times 10^{6} \mathrm{~kg} \text { glass }
$$

Volume of glass made from supernate

$$
4.86 \times 10^{6} \mathrm{~kg} \text { glass }\left(\frac{1 \mathrm{~m}^{3}}{2.6 \mathrm{MT}}\right)\left(\frac{1 \mathrm{MT}}{1000 \mathrm{~kg}}\right)=1.87 \times 10^{3} \mathrm{~m}^{3} \text { glass }
$$

Concentration of TRU in glass without pretreatment

$$
\frac{5.28 \times 10^{2} \mathrm{Ci}\left(\frac{1 \eta \mathrm{Ci}}{1.00 \times 10^{-9} \mathrm{Ci}}\right)}{\left(4.86 \times 10^{6} \mathrm{~kg} \text { glass }\right)\left(\frac{1000 \mathrm{~g}}{1 \mathrm{~kg}}\right)}=109 \frac{\eta \mathrm{Ci}}{\mathrm{g}}
$$

TRU removal efficiency needed

$$
\text { Removal Efficiency }=\left(1-\frac{50 \frac{\eta C i}{g}}{109 \frac{\eta C i}{g}}\right) 100=54.0 \%
$$

Concentration of ${ }^{90} \mathrm{Sr}$ in glass without pretreatment

$$
\frac{2.26 \times 10^{5} \mathrm{Ci}}{1.87 \times 10^{3} \mathrm{~m}^{3} \mathrm{glass}}=121 \frac{\mathrm{Ci}}{\mathrm{m}^{3}}
$$

${ }^{90} \mathrm{Sr}$ removal efficiency needed

$$
\text { Removal Efficiency }=\left(1-\frac{20 \frac{C i}{m^{3}}}{121 \frac{C i}{m^{3}}}\right) 100=91.7 \%
$$


RPP-RPT-48340, Rev. 0

\section{AN-107}

Mass of glass made from supernate

$$
\left(6.77 \times 10^{5} \mathrm{~kg} \mathrm{Na}\right)\left(\frac{1 \mathrm{~kg} \text { glass }}{0.15 \mathrm{~kg} \mathrm{Na}}\right)=4.56 \times 10^{6} \mathrm{~kg} \text { glass }
$$

Volume of glass made from supernate

$$
4.56 \times 10^{6} \mathrm{~kg} \text { glass }\left(\frac{1 \mathrm{~m}^{3}}{2.6 \mathrm{MT}}\right)\left(\frac{1 \mathrm{MT}}{1000 \mathrm{~kg}}\right)=1.75 \times 10^{3} \mathrm{~m}^{3} \text { glass }
$$

Concentration of TRU in glass without pretreatment

$$
\frac{3.18 \times 10^{3} \mathrm{Ci}\left(\frac{1 \eta \mathrm{Ci}}{1.00 \times 10^{-9} \mathrm{Ci}}\right)}{\left(4.56 \times 10^{6} \mathrm{~kg} \text { glass }\right)\left(\frac{1000 \mathrm{~g}}{1 \mathrm{~kg}}\right)}=696 \frac{\eta \mathrm{Ci}}{\mathrm{g}}
$$

TRU removal efficiency needed

$$
\text { Removal Efficiency }=\left(1-\frac{50 \frac{\eta C i}{g}}{696 \frac{\eta C i}{g}}\right) 100=92.8 \%
$$

Concentration of ${ }^{90} \mathrm{Sr}$ in glass without pretreatment

$$
\frac{2.30 \times 10^{5} \mathrm{Ci}}{1.75 \times 10^{3} \mathrm{~m}^{3} \mathrm{glass}}=131 \frac{\mathrm{Ci}}{\mathrm{m}^{3}}
$$

${ }^{90} \mathrm{Sr}$ removal efficiency needed

$$
\text { Removal Efficiency }=\left(1-\frac{20 \frac{C i}{m^{3}}}{131 \frac{C i}{m^{3}}}\right) 100=92.4 \%
$$


RPP-RPT-48340, Rev. 0

\section{APPENDIX B: CRITERIA WEIGHTING PROCESS}

Criteria

Raw Score

(Weight)

A. Removal Efficiency

12

B. Processing Conditions

C. Additional Waste Generation

D. Schedule Impact

\begin{tabular}{c}
12 \\
\hline 8 \\
\hline 0 \\
\hline 3 \\
\hline
\end{tabular}

Most Important (First Decision)

Compare A to B and decide which is most important or if they are equal. Next determine difference in importance using Second Decision guidance. Insert number in box at juncture of criteria being compared. Compare A to all other criteria using the same process. When finished with A follow the procedure

A

\begin{tabular}{|c|c|c|}
\hline \multicolumn{1}{c}{ B } & \multicolumn{1}{c}{ C } & D \\
\hline A & A & A \\
4 & 4 & 4 \\
\hline B & B & B \\
& 4 & 4 \\
\hline \multicolumn{1}{c}{ C } & D \\
\cline { 3 - 3 } & 3 \\
\hline
\end{tabular}
for each remaining criteria.

How Much More Important (Second Decision)

4 - Major preference

3-Medium preference

2-Minor preference

1- Letter/Letter/ - no preference

each scored one point

Note: Sum the numbers for each letter. This is its weight.

Drop Criteria of zero or with a Raw Score of 1. (Criteria which gets dropped may be considered in Advantages/Disadvantages Analysis) 